Article

\title{
Theoretical Study on Electronic Structural Properties of Catalytically Reactive Metalloporphyrin Intermediates
}

\author{
Meijuan Cao ${ }^{1}$, Aijing Gao ${ }^{1}$, Yuanyuan Liu ${ }^{2,3}$, Yang Zhou ${ }^{2,3, * \mathbb{D}}$, Zhicheng Sun ${ }^{1, * \mathbb{D}}$, Yaling Li ${ }^{1}$, \\ Furui $\mathrm{He}^{2,3}$, Luhai $\mathrm{Li}^{1, *}$, Lixin Mo ${ }^{1} \oplus$, Ruping Liu ${ }^{1}$, Yumeng Han ${ }^{1}$ and Yonggang Yang ${ }^{1}$ \\ 1 Beijing Engineering Research Center of Printed Electronics, Beijing Institute of Graphic Communication, \\ Beijing 102600, China; meijuancao@126.com (M.C.); J842320906@163.com (A.G.); liyaling@bigc.edu.cn (Y.L.); \\ molixin@bigc.edu.cn (L.M.); liuruping@bigc.edu.cn (R.L.); hanyumeng7@163.com (Y.H.); \\ yangyonggang@bigc.edu.cn (Y.Y.) \\ 2 School of Chemical Engineering, Technology, Hainan University, Haikou, Hainan 570228, China; \\ yyliu@hainanu.edu.cn (Y.L.); hefurui@foxmail.com (F.H.) \\ 3 Key Laboratory of Advanced Materials of Tropical Island Resources of Ministry of Education, Hainan \\ University, Haikou, Hainan 570228, China \\ * Correspondence: yzhou@hainanu.edu.cn (Y.Z.); sunzhicheng@bigc.edu.cn (Z.S.); liluhai@bigc.edu.cn (L.L.)
}

Received: 15 December 2019; Accepted: 5 February 2020; Published: 13 February 2020

\begin{abstract}
Metalloporphyrins have attracted great attention in the potential application of biomimetic catalysis. Especially, they were widely investigated as green catalysts in the chemical oxidation of various hydrocarbons through the catalytic activation of molecular oxygen. The structural properties of active central metal ions were reported to play a decisive role in catalytic activity. However, those delicate structural changes are difficult to be experimentally captured or elucidated in detail. Herein, we explored the electronic structural properties of metalloporphyrins (metal porphyrin (PM ${ }^{\mathrm{II}}$, $\left.\mathrm{PM}^{\mathrm{III}} \mathrm{Cl}\right)$ ) and their corresponding catalytically active intermediates (metal(III)-peroxo($\left(\mathrm{PM}^{\mathrm{III}}-\mathrm{O}_{2}\right)$, metal(III)-hydroperoxo(PM $\left.{ }^{\mathrm{III}}-\mathrm{OH}\right)$, and metal(IV)-oxo( $\left.\mathrm{PM}^{\mathrm{IV}}=\mathrm{O}\right),(\mathrm{M}=\mathrm{Fe}, \mathrm{Mn}$, and $\mathrm{Co})$ ) through the density functional theory method. The ground states of these intermediates were determined based on the assessment of relative energy and the corresponding geometric structures of ground states also further confirmed the stability of energy. Furthermore, our analyses of Mulliken charges and frontier molecular orbitals revealed the potential catalytic behavior of reactive metalloporphyrin intermediates.
\end{abstract}

Keywords: density functional theory; porphyrin intermediates; ground state; Mulliken charge; frontier molecular orbital (FMO)

\section{Introduction}

Metalloporphyrins have been widely used as impressive catalysts in broad chemical reactions [17], including hydroxylation [8,9], epoxidation [10,11], reduction of nitric oxide [12], oxidation of sulfides [13], radical reactions [14,15], halogenation [16], cycloaddition [17,18], and reduction [19,20]. During the application of metalloporphyrins, the characterization of reactive intermediates is of great importance for the understanding of reaction mechanism. For example, Ali et al. explored the electronic structure, spin-states, and spin-crossover reaction of heme-related Fe-porphyrins based on density functional theory (DFT) calculations [21]. In the mechanistic studies, high-valent iron(IV)-oxo species have been implicated as the key reactive intermediates in the catalytic cycles of alkanes oxidation by heme and non-heme iron enzymes [22-24], as well as the $\mathrm{Mn}$ and Co-oxo species [25-29]. In addition, spectroscopic characterization found a hydroperoxo-heme intermediate converted from a side-on peroxo to an end-on hydroperoxo complex [30]. The low-spin end-on ferric peroxo heme 
intermediate has been proposed as an alternative reactive intermediate in the one electron reduction of a ferric heme [31]. Furthermore, the electronic structure of substituted iron(II) porphyrins has been theoretically studied with intermediate or high spin state [32]. The oxygen activation associated with $\mathrm{Co}, \mathrm{Mn}$, and Mo porphyrins has been studied by quantum chemical methods [33]. Moreover, ferric-superoxo complexes in the oxygen activation by non-heme iron(II) complex were understood by the theoretical calculations [34]. Hydrogen peroxide activated by high-valent heme centers was investigated by density functional theory, implicating its catalytic ability in the catalytic cycle [35]. Therefore, theoretical calculation and spectroscopic characterization are mostly employed for the mechanistic studies of these catalytic reactions involved with metalloporphyrins.

To the best of our knowledge, porphyrins and metalloporphyrins are considered as the most popular biometric catalysts in the functionalization of $\mathrm{C}-\mathrm{H}$ with various substrates. For instance, alkane can be readily activated by a homogeneous manganese (III) porphyrin-iodosyl benzene oxidizing system [36]. Manganese porphyrins could also selectively catalyze the halogenations of $\mathrm{C}-\mathrm{H}$ bond [3]. Oxidation of cyclohexene via molecular oxygen can be completed by cobalt porphyrin complexes immobilized on montmorillonite [37]. In addition to these experimental studies, theoretical studies were also widely performed to understand the catalytic role of these metalloporphyrins. For example, a DFT study found that tetra-amido macrocyclic ligands were substantially noninnocent to high-valent iron, cobalt, and nickel tetraamidomacrocyclic ligand (TAML) complexes [38]. A quantitative structure-activity relationship model (QSAR) study on metalloporphyrin catalysts was carried out in the oxidation of cyclohexane to adipic acid [39]. Theoretical studies were performed to explore a unique class of reactive molecules of iron(III)-nitro porphyrins [40,41]. Despite the diversity of active sites reported, a common mechanistic hypothesis for dioxygen activation is emerging. In this unified approach [42-44], dioxygen might initially bind to a reduced metal center to form a metal-superoxo complex, and subsequently the peroxo intermediates [42,45]. Then, O-O bond cleavage of metal-hydroperoxo species possibly results in the formation of high-valent metal-oxo oxidants $[4,46,47]$, which are considered as the reactive species to oxidize the substrates. Therefore, it is significantly important to determine the corresponding reactive intermediates and evaluate their chemical properties.

Although the wide utilization of metalloporphyrins in the catalytic oxidation of alkanes, the reactive intermediates are difficult to be captured and the electronic structure properties of intermediates are still unclear thus far. In fact, the electronic structure of these reaction intermediates of metalloporphyrins plays a key role in the determination of their function and reactivity [48]. In this work, we explored the intermediates of electronic and geometric properties in the activation of molecular oxygen via metalloporphyrins based on the DFT calculations. Firstly, the ground state of the metalloporphyrin intermediates was evaluated by calculating the relative energy of intermediates. Then, the geometric structure of the ground state intermediates was compared with the data of experiments and then the electronic structure of ground state was confirmed to be stable. Finally, the electronic property of the intermediates was analyzed to give a deep insight into catalytic behavior of porphyrin in the oxidation reaction of alkanes.

\section{Computational Methods}

The selection of proper calculation methods is essentially important to obtain reliable molecular structures and properties. In this study, DFT calculations were carried out using the Amsterdam density functional (ADF2009.01) program package developed by Baerends and his co-workers [49-51]. All metalloporphyrin compounds were optimized with OLYP (unrestricted formalism) generalized gradient approximations based on the OPTX exchange functional [52,53]. The OLYP functional was reported to show great performance in the calculation of metal-complexes $[54,55]$. Various density functional predict methods could provide greatly different results. Specifically, OLYP was proved to be an appropriate model for the oxygen bonding with metalloporphyrins [54,56-58]. Any spin contamination observed in our calculation was ignored due to their low influence $(<5 \%)$. To obtain 
accurate results, the triple- $\zeta$ plus polarization slater-type orbital basis sets (TZP) and a fine mesh numerical integration of the matrix elements were employed. The sub-valence $3 \mathrm{~s}$ and $3 p$ shells of the metal center were included in the valence set. For $C$ and $N$ atoms, $2 s$ and $2 p$ were considered as valence shells, respectively. The other shells of lower energy, such as [Ne] for the metal and $[\mathrm{He}]$ for $\mathrm{C} / \mathrm{N}$, were described as the core. The specific structures of calculated intermediates are listed in Figure 1.

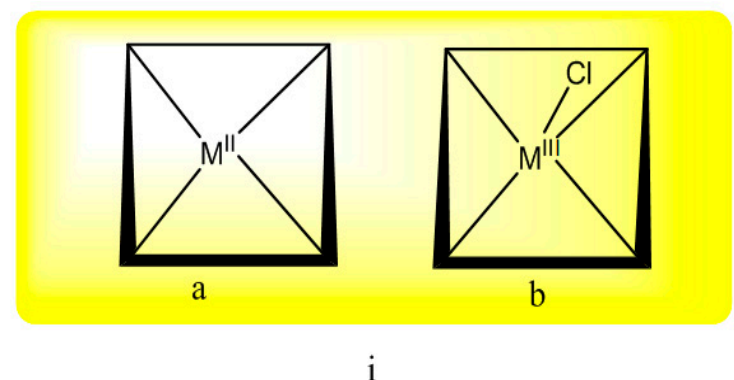

i

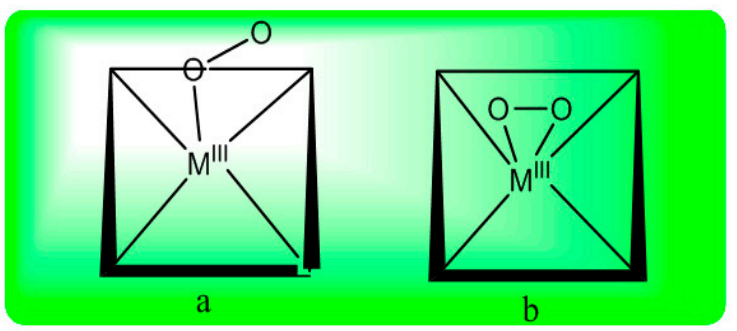

ii

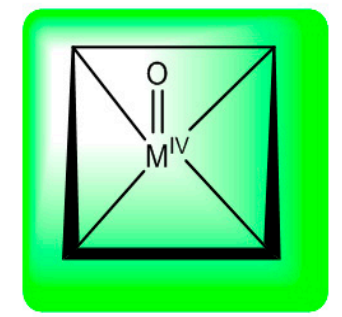

iii

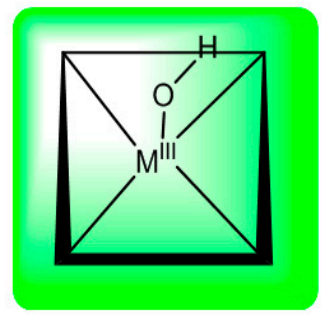

iv

$\mathrm{M}=\mathrm{Fe}, \mathrm{Mn}, \mathrm{Co}$

Figure 1. The geometric structure of metalloporphyrins and intermediates: (i) metalloporphyrin, $\mathrm{PM}^{\mathrm{II}}, \mathrm{PM}^{\mathrm{III}} \mathrm{Cl}$; (ii) metal(III)-peroxo complex, $\mathrm{PM}^{\mathrm{III}}-\mathrm{O}_{2}$; (iii) metal(IV)-oxo complex, $\mathrm{PM}^{\mathrm{IV}} \mathrm{O}$; and (iv) metal(III)-hydroxy complex, $\mathrm{PM}^{\mathrm{III}} \mathrm{OH}$.

\section{Results and Discussion}

\subsection{The Ground State}

To determine the ground states of the metalloporphyrins and intermediates shown in Figure 1, the relative energy of metalloporphyrins with various possible spin states were calculated. As listed in Table 1, $\mathrm{PFe}^{\mathrm{II}}$ has an $\mathrm{S}=1$ ground state, arising from the $(\mathrm{dxy})^{2}\left(\mathrm{dz}^{2}\right)^{2}(\mathrm{~d} \pi)^{2}$ configuration. Typically, $\mathrm{Fe}^{\mathrm{II}}$ ion $\left(\mathrm{d}^{6}\right)$ has a ${ }^{5} \mathrm{~T}_{2 \mathrm{~g}}$ ground state from the ligand field. Therefore, our calculated results were consistent with both experimental and theoretical observations $[59,60]$. The $\mathrm{S}=2$ state of $\mathrm{PFe}^{\mathrm{II}}$ is an intermediate state with an energy level of $112.90 \mathrm{kcal} \cdot \mathrm{mol}^{-1}$ higher than the ground state. In addition, the $S=0$ state of $\mathrm{PFe}^{\mathrm{II}}$ is the high spin state with an energy of $191.66 \mathrm{kcal}^{\mathrm{mol}}{ }^{-1}$. For PMn ${ }^{\mathrm{II}}$ species, we obtained an $\mathrm{S}=3 / 2$ ground state, which is in agreement with Liao's theoretical work [61]. Furthermore, our results indicate that $\mathrm{PCo} \mathrm{O}^{\mathrm{II}}$ has an $\mathrm{S}=1 / 2$ ground state, which is consistent with the configuration assignment $(\mathrm{dxy})^{2}(\mathrm{~d} \pi)^{4}\left(\mathrm{dz}^{2}\right)^{1}$ reported by the Lin group based on those Electron Spin Resonance (ESR) spectra [62].

Table 1. Energies (in kcal.mol ${ }^{-1}$ ) of $\mathrm{PM}^{\mathrm{II}}$ and $\mathrm{PM}^{\mathrm{III}} \mathrm{Cl}(\mathrm{M}=\mathrm{Fe}, \mathrm{Mn}$, and Co).

\begin{tabular}{ccccccccc}
\hline Spin States(S) & Electronic Figuration & $\mathbf{0}$ & $\mathbf{1 / 2}$ & $\mathbf{1}$ & $\mathbf{3 / 2}$ & $\mathbf{2}$ & $\mathbf{5 / 2}$ & Ground State \\
\hline $\mathrm{PFe}^{\mathrm{II}}$ & $\mathrm{d}^{6}$ & 191.66 & - & 0.00 & - & 112.90 & - & $1[41,42]$ \\
$\mathrm{PMn}^{\mathrm{II}}$ & $\mathrm{d}^{5}$ & - & 1207.73 & - & 0 & - & 136.53 & $3 / 2[43]$ \\
$\mathrm{PCo}$ & $\mathrm{d}^{7}$ & - & 0 & - & 86.64 & - & - & $1 / 2[44,45]$ \\
$\mathrm{PFe}^{\mathrm{III}} \mathrm{Cl}$ & $\mathrm{d}^{5}$ & - & 44.63 & - & 0.00 & - & 18.38 & $3 / 2[46], 5 / 2[47]$ \\
$\mathrm{PMn}^{\mathrm{III}} \mathrm{Cl}$ & $\mathrm{d}^{4}$ & 388.57 & - & 68.26 & - & 0 & - & $2[48]$ \\
$\mathrm{PCo}^{\mathrm{III}} \mathrm{Cl}$ & $\mathrm{d}^{6}$ & 0 & - & 31.51 & - & 63.01 & - & - \\
\hline
\end{tabular}


To the best of our knowledge, the spin state of $\mathrm{Fe}^{\mathrm{III}}\left(\mathrm{d}^{5}\right)$ is complicated, due to the possible existence of two energy low-lying states, including intermediate state $(S=3 / 2)[61,63]$ and the high-spin one $(S=5 / 2)[64,65]$. As shown in Table 1, our calculated results show that spin quantum number (S) of the ground state is $3 / 2$ for $\mathrm{PFe}^{\mathrm{III}} \mathrm{Cl}$, while the high spin $(\mathrm{S}=5 / 2)$ was obtained with a slightly higher energy level of $18.38 \mathrm{kcal}^{\mathrm{mol}}{ }^{-1}$. This result suggests that a mixed state of $\mathrm{S}=3 / 2$ and $5 / 2$ might be observed for $\mathrm{PFe}{ }^{\mathrm{III}} \mathrm{Cl}$ complex, consistent with spin states studied by magnetic moments and Moessbauer parameters [66]. Furthermore, the ground state of $\mathrm{Mn}^{\mathrm{III}}$ complexes was determined to be $\mathrm{S}=2$ state, which agrees with the DFT theoretical results reported by Kepenekian et al. [67]. The high spin ground state of $\mathrm{PMn}{ }^{\mathrm{III}} \mathrm{Cl}$ probably resulted from the redistribution of both $\sigma$ and $\pi$ charges. Co ${ }^{\mathrm{III}}$ cation with $\mathrm{d}^{6}$ electronic configuration $\mathrm{PCo}{ }^{\mathrm{III}} \mathrm{Cl}$ was obtained with an $\mathrm{S}=0$ ground state according to our calculation results.

These mononuclear meta-dioxygen $\left(\mathrm{PM}^{\mathrm{III}}-\mathrm{O}_{2}\right)$ adducts were implicated as key intermediates in dioxygen activation reactions catalyzed by metalloenzymes. Thus, the structural and the electronic properties of these reactive species are helpful to understand their biological or chemical roles of catalytic activities. As mentioned above, dioxygen may be bound to the metal center through either end-on or side-on approach. According to the data listed in Table 2, the DFT energetic results suggested that both side-on $\mathrm{PFe}^{\mathrm{III}}-\mathrm{O}_{2}$ and end-on $\mathrm{PFe}^{\mathrm{III}}-\mathrm{O}_{2}$ have the $\mathrm{S}=0$ ground state. The side-on $\mathrm{PMn}^{\mathrm{III}} \mathrm{O}_{2}$ has an $\mathrm{S}=3 / 2$ ground state, while the end-on $\mathrm{PMn}^{\mathrm{III}}-\mathrm{O}_{2}$ has an $\mathrm{S}=5 / 2$ ground state. Additionally, the end-on $\mathrm{PCo}^{\mathrm{III}}-\mathrm{O}_{2}$ has an $\mathrm{S}=1 / 2$ ground state.

Table 2. Relative energies of the intermediates $\mathrm{PM}^{\mathrm{II}} \mathrm{O}_{2}(\mathrm{M}=\mathrm{Fe}, \mathrm{Mn}$, and Co).

\begin{tabular}{cccccccc}
\hline Spin States(S) & Electronic Configuration & $\mathbf{0}$ & $\mathbf{1 / 2}$ & $\mathbf{1}$ & $\mathbf{3 / 2}$ & $\mathbf{2}$ & $\mathbf{5} / \mathbf{2}$ \\
\hline $\mathrm{PFe}^{\mathrm{III}} \mathrm{O}_{2}$-side-on & - & 0.00 & - & 18.38 & - & 94.52 & - \\
$\mathrm{PFe}^{\mathrm{III}} \mathrm{O}_{2}$-end-on & $\mathrm{d}^{5}$ & 0.00 & - & 21.00 & - & 73.51 & - \\
$\mathrm{PMn}^{\mathrm{III}} \mathrm{O}_{2}$-side-on & $\mathrm{d}^{4}$ & - & 73.51 & - & 0 & - & 52.51 \\
$\mathrm{PMn}^{\mathrm{III}} \mathrm{O}_{2}$-end-on & $\mathrm{d}^{4}$ & - & 10.50 & - & 2.63 & - & 0 \\
$\mathrm{PCo}^{\mathrm{III}} \mathrm{O}_{2}$-end-on & $\mathrm{d}^{6}$ & - & 0 & - & 47.26 & - & - \\
\hline
\end{tabular}

The oxidative manganese (IV) intermediates were reported to include either hydroxo or oxo ligand. The high-valent iron(IV)-oxo species have been proposed as an oxidant intermediate in the $\mathrm{C}-\mathrm{H}$ abstraction reaction. As shown in Table 3, $\mathrm{PFe}^{\mathrm{IV}} \mathrm{O}$ was calculated to have an $\mathrm{S}=1$ ground state and an $\mathrm{S}=2$ active state. This intermediate had a high spin $(\mathrm{S}=2)$ iron(IV)-oxo unit with a double bond character between iron center and oxygen atom. In contrast, $\mathrm{PMn}^{\mathrm{IV}} \mathrm{O}$ had an $\mathrm{S}=1 / 2$ ground state with three unpaired electrons distributed between manganese and oxygen atom in a ratio of 1:2. The active state had a higher energy level $\left(68.26 \mathrm{kcal} \mathrm{mol}^{-1}\right)$ than the ground state. Based on Shaik's two-state theory [68], the high spin state of $\mathrm{PFe}^{\mathrm{IV}} \mathrm{O}$ was assumed to have a higher catalytic reactivity in the $\mathrm{C}-\mathrm{H}$ oxidation. Our energetic calculations found that $\mathrm{PCo}^{\mathrm{IV}} \mathrm{O}$ had an $\mathrm{S}=3 / 2$ ground state and an $\mathrm{S}=5 / 2$ active state. These calculated energetic results demonstrate reasonable spin sate for the high-valent species.

Table 3. Relative energies of $\mathrm{PM}^{\mathrm{IV}} \mathrm{O}$ and $\mathrm{PM}{ }^{\mathrm{III}} \mathrm{OH}(\mathrm{M}=\mathrm{Fe}, \mathrm{Mn}$, and $\mathrm{Co})$.

\begin{tabular}{ccccccccc}
\hline Spin States(S) & Electronic Configuration & $\mathbf{0}$ & $\mathbf{1 / 2}$ & $\mathbf{1}$ & $\mathbf{3 / 2}$ & $\mathbf{2}$ & $\mathbf{5 / 2}$ & Ground State \\
\hline $\mathrm{PFe}^{\mathrm{IV}} \mathrm{O}$ & $\mathrm{d}^{4}$ & 84.02 & - & 0.00 & - & 68.26 & - & 1 \\
$\mathrm{PMn}^{\mathrm{IV}} \mathrm{O}$ & $\mathrm{d}^{3}$ & - & 0 & - & 44.63 & - & - & - \\
$\mathrm{PCo}^{\mathrm{IV}} \mathrm{O}$ & $\mathrm{d}^{5}$ & - & 433.21 & - & 0 & - & 147.29 & - \\
$\mathrm{PFeO}^{\mathrm{III}} \mathrm{H}$ & $\mathrm{d}^{5}$ & - & 42.01 & - & 0.00 & - & 44.63 & $3 / 2$ \\
$\mathrm{PMnO}^{\mathrm{III}} \mathrm{H}$ & $\mathrm{d}^{4}$ & 81.39 & - & 31.51 & - & 0 & - & - \\
$\mathrm{PCoO}^{\mathrm{III}} \mathrm{H}$ & $\mathrm{d}^{6}$ & 0 & - & 94.52 & - & 133.90 & - & - \\
\hline
\end{tabular}

$\mathrm{PMn}{ }^{\mathrm{III}} \mathrm{OH}$ species was reported to have a similar hydrogen abstraction capability as compared to $\mathrm{PMn}^{\mathrm{IV}}=\mathrm{O}$ [69]. As the reductant of high-valent species, $\mathrm{PFe} \mathrm{III}^{\mathrm{III}}$ was predicted to have an $\mathrm{S}=3 / 2$ ground state, which was different from that of $\mathrm{PFeO}^{\mathrm{III}} \mathrm{H}$ reported in the literature [70]. Furthermore, 
$\mathrm{PMn}{ }^{\mathrm{III}} \mathrm{OH}$ was found with a high-spin ground state $(\mathrm{S}=2)$. However, $\mathrm{PCo}{ }^{\mathrm{III}} \mathrm{OH}$ was shown with a low-spin ground state $(\mathrm{S}=0)$.

\subsection{The Geometric Structure}

To understand the specific structural features, the geometric structure of the ground state intermediates was optimized to confirm the ground state of intermediates. The geometric structure model of intermediates is shown in Figure 2. The calculated geometry parameters are recorded in Figure S1. The data of $\mathrm{C}_{\mathrm{m}}-\mathrm{C}_{\alpha}, \mathrm{C}_{\alpha}-\mathrm{C}_{\beta}, \mathrm{C}_{\alpha}-\mathrm{C}_{\beta}$, and $\mathrm{C}_{\alpha}-\mathrm{N}$ obtained from $\mathrm{PFe}^{\mathrm{II}}$ species agreed well with those parameters reported in the crystal structure [71]. The Fe-N bond length was calculated to be $1.997 \AA$, which is close to that of $2.003 \AA$ reported by Rauk [72]. Typically, the Fe ${ }^{\mathrm{II}}$ was set in plane of the porphyrin. Thus, these calculated geometric parameters of $\mathrm{PFe}^{\mathrm{II}}$ are consistent with experimental values obtained from crystal structures.

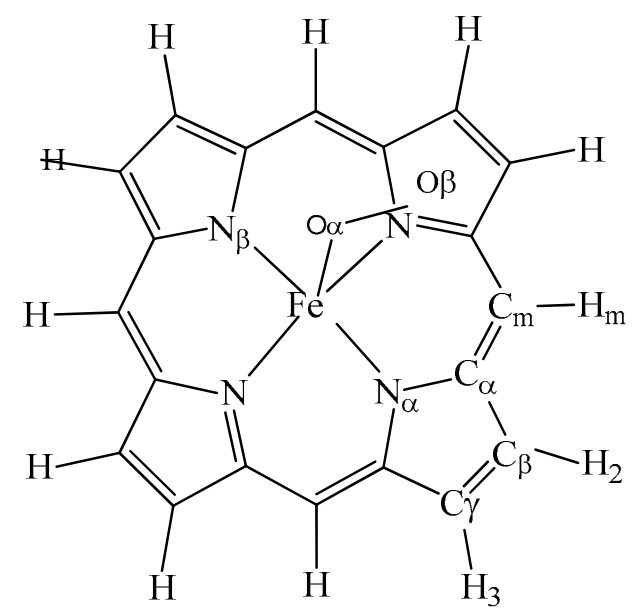

Figure 2. The geometric structure of intermediate.

The geometric structure parameters of $\mathrm{PM}^{\mathrm{III}} \mathrm{Cl}$ are summarized in Figure S2. The bond length of $\mathrm{Fe}-\mathrm{Cl}$ in $\mathrm{PFe}{ }^{\mathrm{III}} \mathrm{Cl}$ was $2.224 \AA$ (exp. $2.221 \AA$ ) and $\mathrm{Fe}-\mathrm{N}$ bond was $2.213 \AA$ (exp. 2.087 $\AA$ ). These calculated bond lengths were consistent with experimental data [73]. The degree of $\angle \mathrm{N}_{\alpha} \mathrm{FeN} \beta$ was $148.8^{\circ}$, which indicated that $\mathrm{Fe}$ atom was stretched out of the plane defined by four $\mathrm{N}$ atoms toward the axial chloride atom. As compared to $\mathrm{PFe} \mathrm{e}^{\mathrm{II}}, \mathrm{Fe}-\mathrm{N}$ bond distance in $\mathrm{PFe}{ }^{\mathrm{III}} \mathrm{Cl}$ was elongated by about $0.2 \AA$. For $\mathrm{PMn}{ }^{\mathrm{III}} \mathrm{Cl}, \mathrm{Mn}-\mathrm{N}$ bond length was $2.002 \AA$ and the axial $\mathrm{Mn}-\mathrm{Cl}$ distance was $2.297 \AA$. Thus, Mn atom was out of the plane by $0.16 \AA$ [74]. Mn-N bond had a length of $1.965 \AA$, which was slightly longer than the experimental value of $1.947 \AA$ [75]. In the model of $\mathrm{PCo}{ }^{\mathrm{III}} \mathrm{Cl}$, the calculated Co-N bond length was $2.006 \AA$, which was shorter than both Mn-N and Fe-N bonds. The C-C bond length was comparable with that of the low-spin cobalt porphyrin reported by the Scheidt group [76]. Thus, our calculated ground states of these complexes were in great agreement with their crystal structures.

The geometric structure parameters of $\mathrm{PM}^{\mathrm{III}} \mathrm{O}_{2}$ were compared with the experimental data to confirm the ground state. As shown in Figure S3, the Fe-O, Fe-N, and O-O bond lengths in PFe ${ }^{\mathrm{III}}$ with end-on oxygen were $1.729,2.023$, and $1.275 \AA$, respectively. For PFe ${ }^{\mathrm{III}}$ with side-on oxygen, the bond lengths of $\mathrm{Fe}-\mathrm{O}$ and $\mathrm{O}-\mathrm{O}$ are higher than those observed in $\mathrm{PFe}{ }^{\mathrm{III}}$ with end-on oxygen. The other bond parameters are greatly close to these values of $\mathrm{PFe}^{\mathrm{III}}$ with end-on oxygen. In addition to a delicate difference observed in $\mathrm{Mn}-\mathrm{N}$ for the Mn porphyrin complexes between side-on and end-on oxygen, all the other bond lengths are almost in the same range. The O-O bond in Co porphyrin complex with end-on oxygen has similar bond length with that of $\mathrm{Fe}^{\mathrm{II}}-\mathrm{O}_{2}$, but $\mathrm{Co}-\mathrm{O}$ bond is slightly longer than $\mathrm{Fe}-\mathrm{O}$ bond. Interestingly, as compared to both $\mathrm{Fe}$ and $\mathrm{Mn}$ porphyrins, Co porphyrin was observed with little change for the peroxo side-on geometry (data not shown). Therefore, the coordination of 
oxygen on the metalloporphyrins influences the structure of metal center cores, but it shows little effect on the porphyrin ligand plane.

To understand the structure of metal centers, it would be of significance to inspect the M-O-O angles obtained from these reactive species. The corresponding angle data are summarized in Figure 3. For these end-on oxygen adducts, $\mathrm{M}-\mathrm{O}-\mathrm{O}$ angles are much larger than those of side-on complexes. For Fe and Mn porphyrins with end-on oxygen, the same M-O-O angles $\left(\sim 124.3^{\circ}\right)$ were observed, which are much higher than that of $\mathrm{Co}-\mathrm{O}-\mathrm{O}\left(\sim 110^{\circ}\right)$ in Co porphyrin. The angles of Fe/Mn-O-O were close to $120^{\circ}$, indicating that these orbitals have the property of $\mathrm{sp}^{2}$-like bonding. Specifically, the O-O bond length in these metalloporphyrin adducts with end-on oxygen was $1.275(\mathrm{Fe}), 1.382(\mathrm{Mn})$, and 1.280 (Co) $\AA$, respectively. As compared to regular O-O bond length in molecular oxygen, these bond length values indicated that $\mathrm{O}_{2}$ has been greatly elongated in the $\mathrm{PM}^{\mathrm{III}}-\mathrm{O}_{2}$ adducts. Due to the elongation of $\mathrm{O}-\mathrm{O}$ bond, we presumed that high valent metalloporphyrin species can be generated from the cleavage of $\mathrm{O}-\mathrm{O}$ bond. Fe and $\mathrm{Mn}$ porphyrins with the side-on oxygen showed a much lower M-O-O angle value $\left(>50^{\circ}\right)$ than those observed in end-one model. However, Mn-O-O angle was slightly higher ( $10^{\circ}$ ) than that of Fe-O-O.

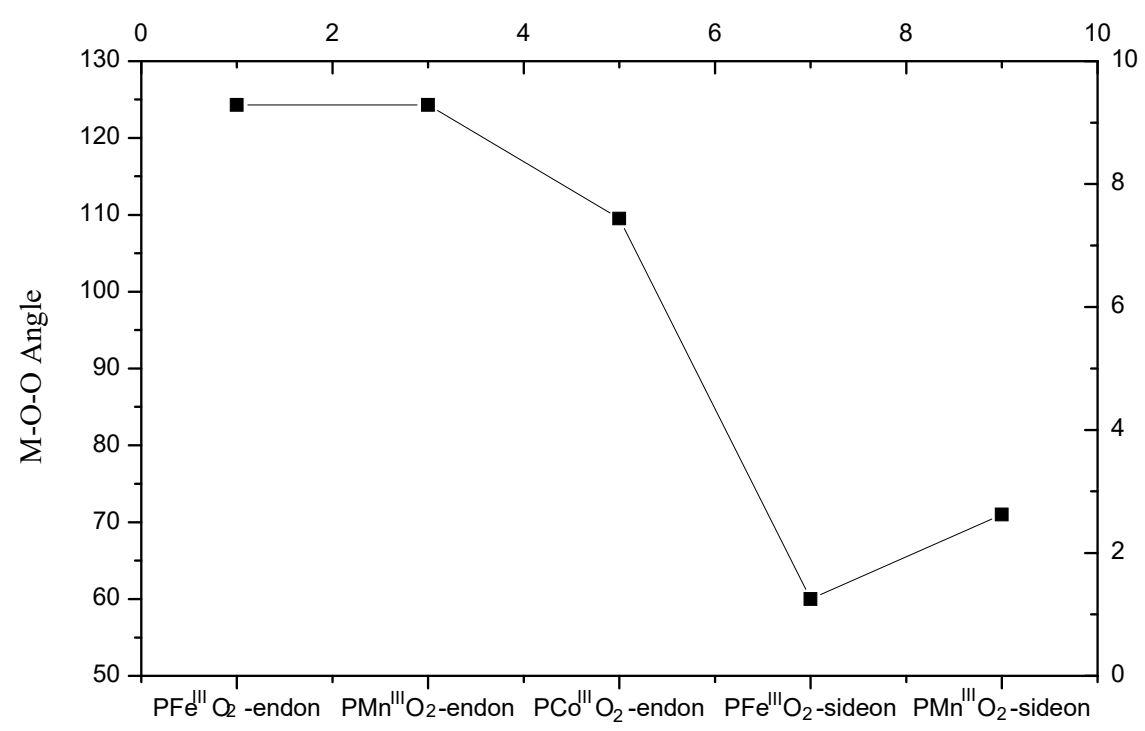

Figure 3. The M-O-O angles of side-on and end-on $\mathrm{PM}^{\mathrm{II}}-\mathrm{O}_{2}$ intermediates.

$\mathrm{M}(\mathrm{IV})=\mathrm{O}$ species was considered as the most reactive intermediate in oxygen activation, which can readily abstract the hydrogen to generate the metal-hydroxy complex. We also investigated the bond length differences of these metal(IV)-oxo and metal(III)-hydroxy complexes (see Figure 4). In addition to the differences obtained from $\mathrm{M}-\mathrm{O}$ and $\mathrm{M}-\mathrm{N}$ bonds, all other chemical bonds show little variations in these intermediates. Therefore, metal center should be the catalytic active site. M-N bonds $(\sim 2.022 \AA)$ for three metal-oxo species are similar to each other. However, Co-O bond $(1.733 \AA)$ is slightly longer than those of $\mathrm{Fe} / \mathrm{Mn}-\mathrm{O}$ bond ( 1.632 $\AA$ ). After the formation of $\mathrm{PM}^{\mathrm{III}} \mathrm{OH}$ species, $\mathrm{M}-\mathrm{N}$ seems to be shortened, while $\mathrm{M}-\mathrm{O}$ bond is observed to be slightly elongated. In $\mathrm{PM}^{\mathrm{III}} \mathrm{OH}$ intermediates, similar M-N bond lengths were observed to be $~ 1.95 \AA$. However, a great difference was observed in $\mathrm{M}-\mathrm{O}$ bond length. Mn-O bond length was $1.952 \AA$, which was longer than that in $\mathrm{PFe} \mathrm{e}^{\mathrm{III}} \mathrm{OH}(1.740 \AA)$ or $\mathrm{PCo}{ }^{\mathrm{III}} \mathrm{OH}(1.850 \AA)$. We expected that a longer $\mathrm{M}-\mathrm{O}$ bond can facilitate the transfer of active oxygen. In addition, the angle of $\mathrm{Fe}-\mathrm{O}-\mathrm{H}$ was $105.5^{\circ}$ in $\mathrm{PFe}{ }^{\mathrm{III}} \mathrm{OH}$, which is slightly smaller than those of $\mathrm{Mn}-\mathrm{O}-\mathrm{H}$ and $\mathrm{Co}-\mathrm{O}-\mathrm{H}$. To the best of our knowledge, $\mathrm{PFe}{ }^{\mathrm{III}} \mathrm{OH}$ was considered to react with alkane radical and to form Fe-O-C in the $\mathrm{OH}$ rebound step. The relative smaller M-O-H angle is likely to facilitate the combination of $\mathrm{PFe}{ }^{\mathrm{III}} \mathrm{OH}$ and alkane radical. 


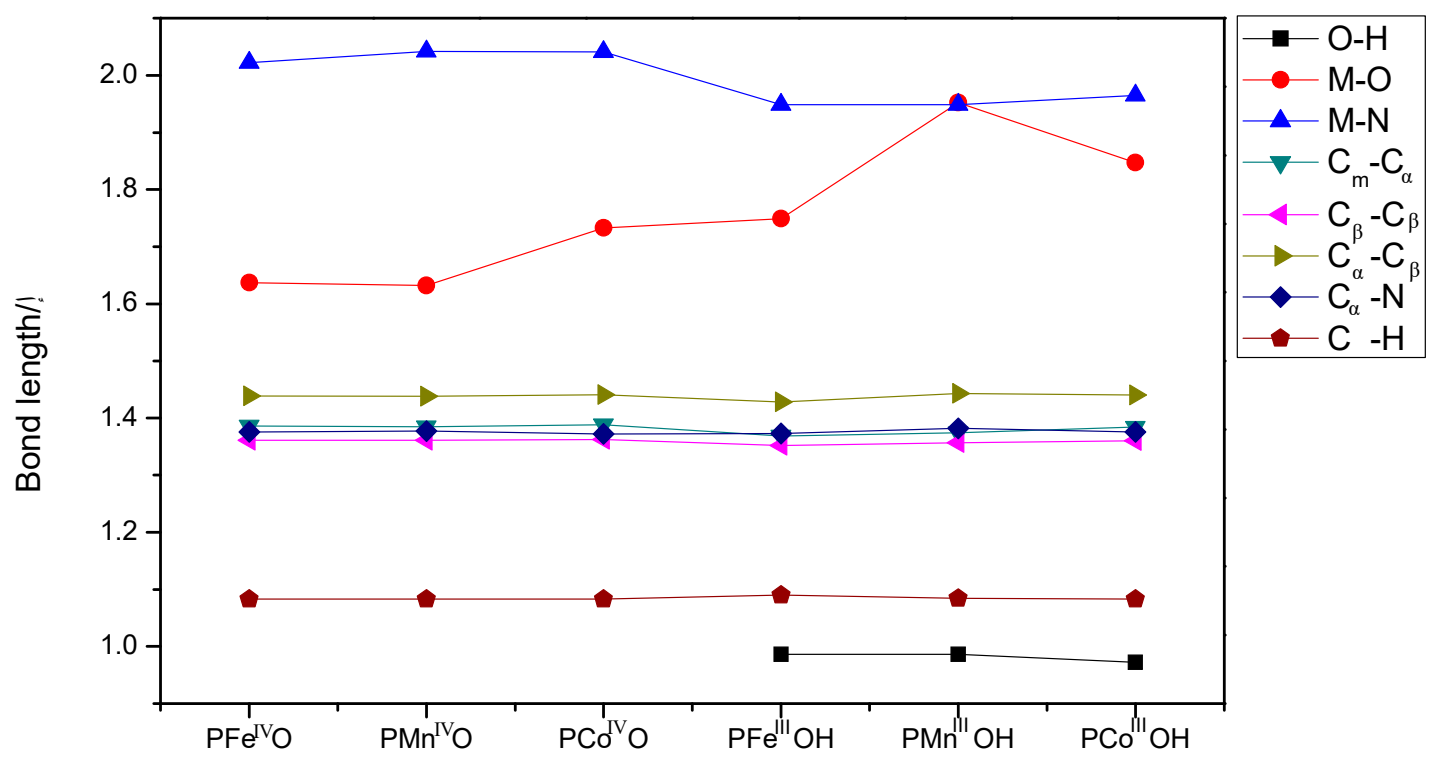

Figure 4. Calculated bond lengths of $\mathrm{PM}^{\mathrm{IV}}=\mathrm{O}$ and $\mathrm{PM}^{\mathrm{III}} \mathrm{OH}(\mathrm{M}=\mathrm{Fe}, \mathrm{Mn}$, and $\mathrm{Co})$ intermediates.

\subsection{Mulliken Charge}

To explore the dedicate structure of intermediates, the Mulliken charge of these metalloporphyrins was also analyzed (see Figure 5A). Interestingly, for all these complexes, the metal center is the most positive site, while $\mathrm{N}$ atoms are present with the most negative charges. Additionally, no great difference was observed in all $\mathrm{H}$ and $\mathrm{C}$ atoms from these metalloporphyrins. Specifically, the charge distributed on $\mathrm{Fe}, \mathrm{Mn}$, and $\mathrm{Co}$ atom was $1.02,1.276$, and 0.846 , respectively. Thus, a more positive charge was observed on $\mathrm{Mn}^{\mathrm{III}}$ than $\mathrm{Fe}^{\mathrm{III}}$ and $\mathrm{Co}^{\mathrm{III}}$ cations. For negative change on $\mathrm{N}$ atoms, those $\mathrm{N}$ atoms from $\mathrm{Mn}^{\mathrm{III}}$ porphyrin had slightly lower negative charge than those present in Fe and Co porphyrins. The charge distribution property of these metalloporphyrins with chloride as axial ligand is similar to the order of that derived from metalloporphyrins without chloride ligand. The metal center and $\mathrm{N}$ atoms in $\mathrm{PMn}{ }^{\mathrm{III}} \mathrm{Cl}$ complex have the highest positive charge and mostly negative charge, respectively. Furthermore, the axial $\mathrm{Cl}$ ligand in $\mathrm{PMn}{ }^{\mathrm{III}} \mathrm{Cl}$ complex also show much negative charge $(-0.5)$, which had a decreased effect on the charge of $\mathrm{Co}^{\mathrm{II}}$ ion. We presumed that the electronic structure can greatly influence the catalytic reactivity, because these metal centers are the active sites for the oxygen absorption and activation. Based on our Mulliken charge distribution results, we concluded that $\mathrm{PMn}^{\mathrm{II}}$ was much easier to combine with molecular oxygen than Fe and Co porphyrins, due to the presence of most positive charge on Mn center.

With the incorporation of oxygen on metal centers, it is clearly observed that Mulliken charges distribution in $\mathrm{PM}^{\mathrm{III}}-\mathrm{O}_{2}$ complexes have been greatly changed as compared to those without oxygen. Furthermore, the charge on end-on $\mathrm{PMn}^{\mathrm{III}}-\mathrm{O}_{2}$ complex was different from metal centers in $\mathrm{PFe}^{\mathrm{III}} \mathrm{O}_{2}$-endon and $\mathrm{PCo}{ }^{\mathrm{III}} \mathrm{O}_{2}$-endon adducts (see Figure $5 \mathrm{~B}$ ). Typically, $\mathrm{Mn}$ center has a slightly higher positive charge than $\mathrm{Fe}$ and $\mathrm{Co}$ Centers. The oxygen located in $\beta$ positions also demonstrate certain differences in the negative charge. In contrast, the negative charge of oxygen atoms in $\alpha$ position show little difference. Additionally, atoms of $\mathrm{H}_{\mathrm{m}}, \mathrm{C}_{\beta}$, and $\mathrm{H}$ presented in the end-on $\mathrm{PMn}^{\text {III }}-\mathrm{O}_{2}$ complex have much lower negative charge than those presented in the other $\mathrm{PM}^{\mathrm{III}}-\mathrm{O}_{2}$ complexes.

Mulliken charges on $\mathrm{PM}^{\mathrm{IV}}=\mathrm{O}$ and $\mathrm{PM}^{\mathrm{III}} \mathrm{OH}$ complexes are shown in Figure 5C. All metal centers have the most positive charge. In addition, we can see that the charge on $\mathrm{Co}^{\mathrm{IV}}$ ion was lower than that of $\mathrm{Fe}^{\mathrm{IV}}$ and $\mathrm{Mn}^{\mathrm{IV}}$ ions for high valent species. The charge on $\mathrm{O}$ atom was $-0.508|\mathrm{e}|$ for $\mathrm{PFe}^{\mathrm{IV}} \mathrm{O}$ and $\mathrm{PCo}^{\mathrm{IV}} \mathrm{O}$, but it was only $-0.213|\mathrm{e}|$ for $\mathrm{PMn}^{\mathrm{IV}} \mathrm{O}$. The negative charge on $\mathrm{O}$ atoms can be employed to estimate the hydrogen abstraction ability of these complexes. The more negative charge indicated that $\mathrm{PFe}^{\mathrm{IV}} \mathrm{O}$ and $\mathrm{PCo}^{\mathrm{IV}} \mathrm{O}$ can more readily abstract $\mathrm{H}$ atom from $\mathrm{C}-\mathrm{H}$ bond in substrates. 

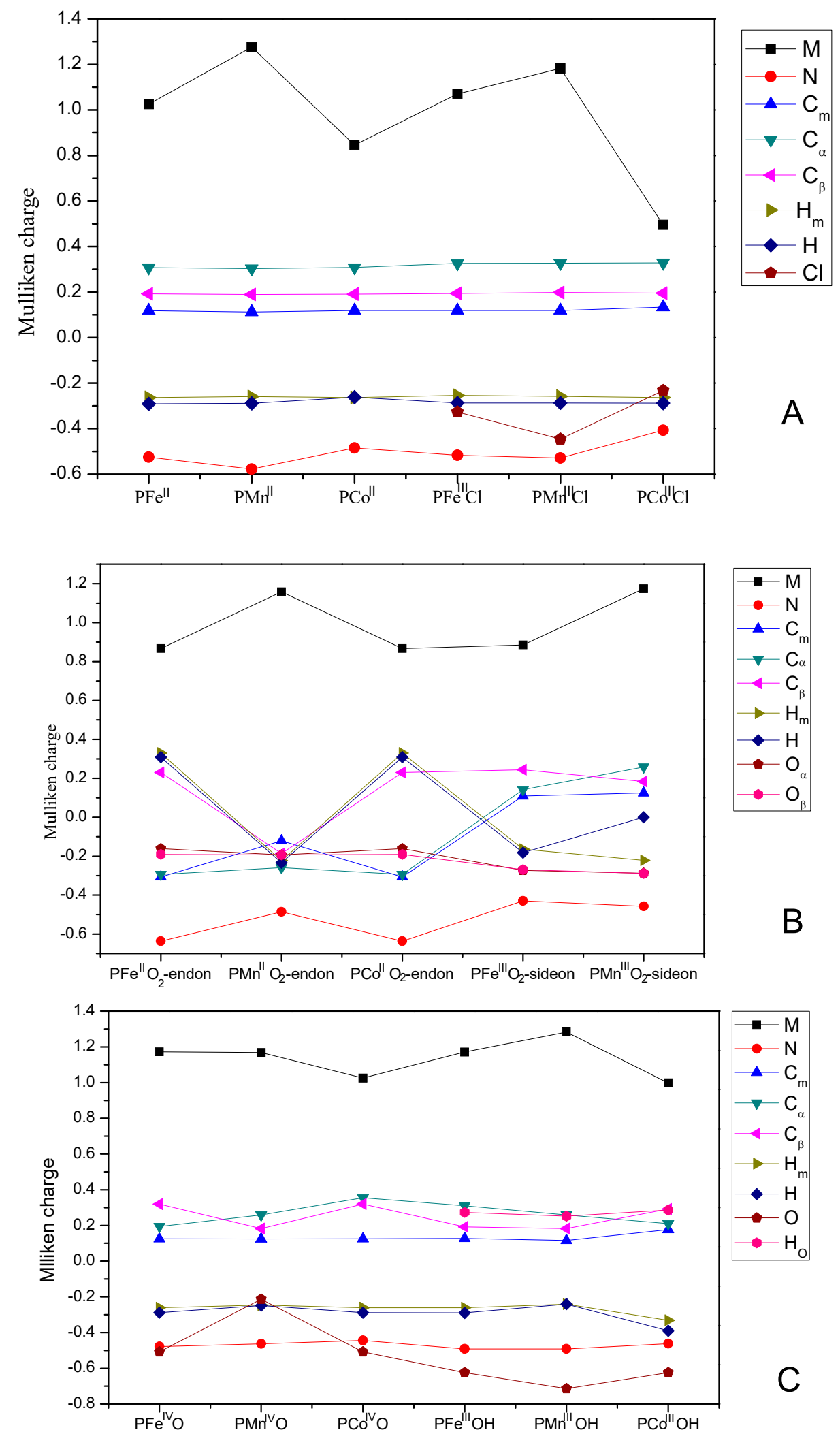

Figure 5. Mulliken charges on: (A) $\mathrm{PM}^{\mathrm{II}} / \mathrm{PM}^{\mathrm{III}} \mathrm{Cl}(\mathrm{M}=\mathrm{Fe}, \mathrm{Mn}$, and $\mathrm{Co})$; (B) $\mathrm{PM}^{\mathrm{III}}-\mathrm{O}_{2}(\mathrm{M}=\mathrm{Fe}, \mathrm{Mn}$, and Co); and (C) $\mathrm{PM}^{\mathrm{IV}}=\mathrm{O} / \mathrm{PM}^{\mathrm{III}} \mathrm{OH}(\mathrm{M}=\mathrm{Fe}, \mathrm{Mn}$, and $\mathrm{Co})$.

For all hydroxy species, $\mathrm{O}$ atoms have more negative charge than these high valent species $\left(\mathrm{PM}^{\mathrm{IV}} \mathrm{O}\right)$. Indeed, $\mathrm{PFe} \mathrm{e}^{\mathrm{III}} \mathrm{OH}$ was considered to combine with alkane radical in the $\mathrm{OH}$ radical rebound 
step. The more negative charge on $\mathrm{O}$ can promote the combination of iron-hydroxo species with alkane radical. The $\mathrm{O}$ atom of $\mathrm{PMn}{ }^{\mathrm{III}} \mathrm{OH}$ is more negative than that of $\mathrm{PFe} e^{\mathrm{III}} \mathrm{OH}$ and $\mathrm{PCo}{ }^{\mathrm{III}} \mathrm{OH}$. Previously, the iron-hydroperoxo species was assumed to be a sluggish oxidant. The oxidation ability of the intermediate cannot compete with that of high-valent iron(IV)-oxo species, while both iron-oxo and iron-hydroperoxo species have been recently proposed as oxidants in cytochrome $\mathrm{P} 450$. The $\mathrm{O}$ atom of $\mathrm{PFe}^{\mathrm{III}} \mathrm{OH}$ is more negative than that in $\mathrm{PFe}^{\mathrm{IV}} \mathrm{O}$, inferring that $\mathrm{Fe}^{\mathrm{III}} \mathrm{OH}$ was expected to be a stronger nucleophilic agent.

\subsection{Frontier Molecular Orbitals}

The bonding properties of metalloporphyrins are important to understand the nature of catalytic process. As shown in Figure 6, $\mathrm{HOMO}$ of $\mathrm{PFe}^{\mathrm{II}}$ was mainly constituted by Fe-dxz orbital, while LUMO was made up by Fe- $\mathrm{dz}^{2}$ orbital. In fact, $\mathrm{Fe}-\mathrm{dz}^{2}$ orbital protruded out of porphyrin surface, which was therefore stereochemically active. In addition, 92.79\% of HOMO in PMn ${ }^{\mathrm{II}}$ complex was $\mathrm{dxy}$ orbital. Unlike Fe center in $\mathrm{PFe}^{\mathrm{II}}$, Mn metal was located within porphyrin plane, exhibiting less stereochemical activity than typical $\mathrm{dz}^{2}$ orbital. Frontier molecular orbital (FMO) of $\mathrm{PCO}^{\mathrm{II}}$ was active in stereochemistry, which is similar to that of $\mathrm{PFe}^{\mathrm{II}}$. However, $\mathrm{PCo}^{\mathrm{II}}$ energy levels of FMO were lower than those of $\mathrm{PFe}^{\mathrm{II}}$ and $\mathrm{PMn}{ }^{\mathrm{II}}$. Indeed, LUMO played an important role with respect to the activation of dioxygen. Once oxygen was coordinated to central iron, oxygen was considered to be activated. The LUMO in these complexes served as an electron acceptor to accept electron from HOMO of oxidant. The lower $\mathrm{E}_{\mathrm{LUMO}}$ reduced FMO energy gap between metalloporphyrin and molecular oxygen, which is favorable in the electron transfer between the catalyst and the oxidant. FMO analysis revealed that $\mathrm{PFe}^{\mathrm{II}}$ and $\mathrm{PCo}{ }^{\mathrm{II}}$ were more stereochemically favorable than $\mathrm{PMn}^{\mathrm{II}}$ in the activation of dioxygen. However, $\mathrm{PCO}^{\mathrm{II}}$ was considered to be the most advantageous in orbital energy. $\mathrm{For} \mathrm{PFe}^{\mathrm{III}} \mathrm{Cl}$, the LUMO was made up with Fe-dxy orbital, while $\mathrm{PMn}{ }^{\mathrm{III}} \mathrm{Cl}$ consisted of $\mathrm{Mn}-\mathrm{dx}^{2}-\mathrm{z}^{2}$ orbital. Both HOMOs of $\mathrm{PFe}^{\mathrm{III}} \mathrm{Cl}$ and $\mathrm{PMn}{ }^{\mathrm{III}} \mathrm{Cl}$ were admixed with $\mathrm{Cl}$-pz orbital to form the hybrid $\mathrm{dz}^{2}$-pz orbital that is much less stereochemically active. The axial chloride lowered energy level of $\mathrm{HOMO}$ and LUMO for $\mathrm{PFe}^{\mathrm{III}} \mathrm{Cl}$ as compared with their counterparts. In contrast to the unligated oxidation, oxidation may occur under the HOMO control approach.

The relative extent of iron-porphyrin interactions can be qualitatively evaluated through spin population and orbital contribution analyses. As shown in Figure 7, the nature of ground state of ferrous ion critically depended upon the energy of $d_{z}{ }^{2}$ orbital relative to those of $d_{x z}$ and $d_{y z}$ orbitals. For most of porphyrin derivatives, the ground state was ${ }^{3} \mathrm{~A}_{2 g}$, which was strongly perturbed by the closely lying ${ }^{3} \mathrm{E}_{\mathrm{g}}$ excited state. This strong mixing with spin-orbit coupling explained the large orbital contribution to magnetic susceptibility of these complexes. A small axial perturbation could induce a reversal of ground state with corresponding inversion of magnetic anisotropy. This was promoted by the back-bonding between the filled dxz orbital of heme-iron and the empty p orbital of carbine. The manganese (IV) species with a $\mathrm{Mn}^{\mathrm{IV}} \mathrm{OH}$ group had a higher redox potential. A ligand $\sigma^{*}$ back bonding interaction existed only in the side-on complexes.

The characteristics of frontier molecular orbital were greatly associated with the properties of catalytic intermediates. Such a state was interpreted in term of a molecular orbital. As shown in Figure 8, The HOMO of $\mathrm{S}=1 \mathrm{PFe}^{\mathrm{IV}} \mathrm{O}$ was consisted of $\mathrm{dxy}$ orbital and O-py orbital, in which they interacted to form $\pi$ orbital. In this case, $\pi$ orbital of $\mathrm{PFe}^{\mathrm{IV}} \mathrm{O}$ attacks the $\mathrm{C}-\mathrm{H}$ bond, and the attack orientation is near to $90^{\circ}$ (perpendicularly). In general, $\mathrm{dz}^{2}$ is a $\sigma^{*}$-type orbital, but the $\mathrm{S}=2 \mathrm{Fe}^{\mathrm{IV}}=\mathrm{O}$ intermediate provides occupied and unoccupied $\pi$ FMOs. These have different orientation dependencies, providing an active site flexibility in using this orientation to control the reactivity. Whereas $\mathrm{PMn}^{\mathrm{IV}}=\mathrm{O}$ species provides the occupied $\pi$ FMOs, $\mathrm{PCO}^{\mathrm{IV}}=\mathrm{O}$ complex gives unoccupied $\sigma$ FMOs. 


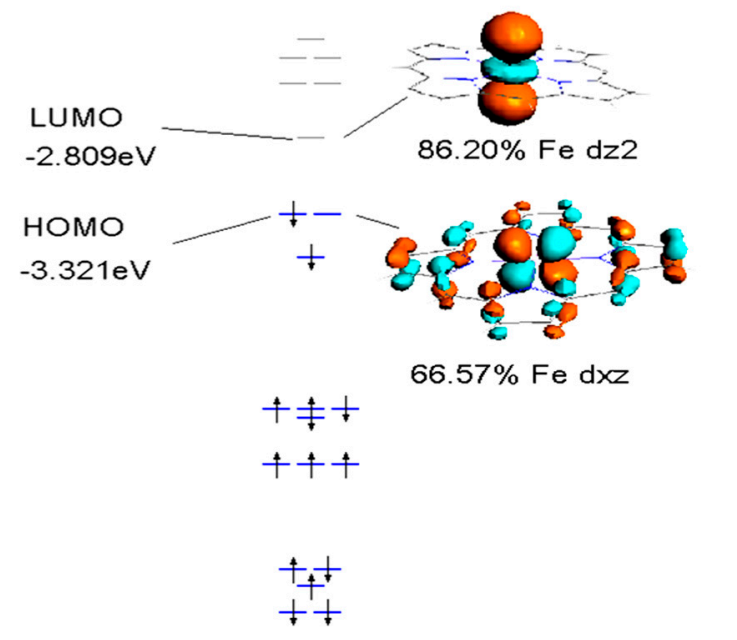

(PFe ${ }^{\mathrm{II}}$ )

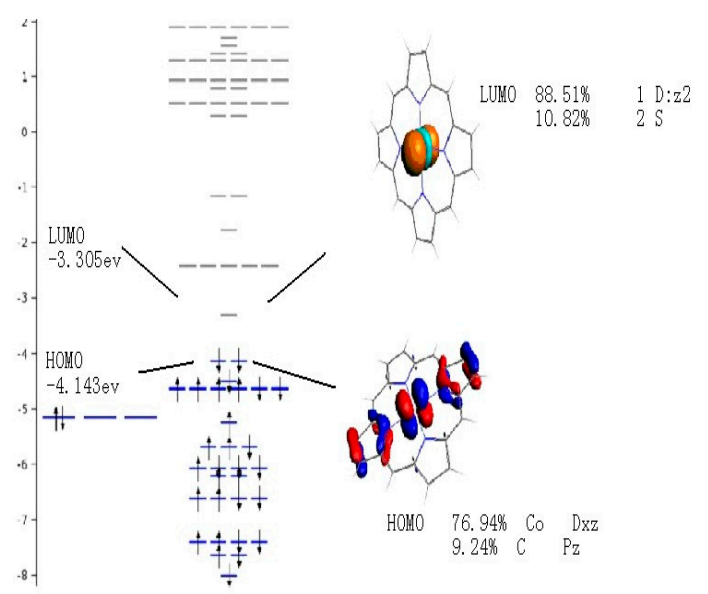

(PCo $\left.{ }^{\text {II }}\right)$

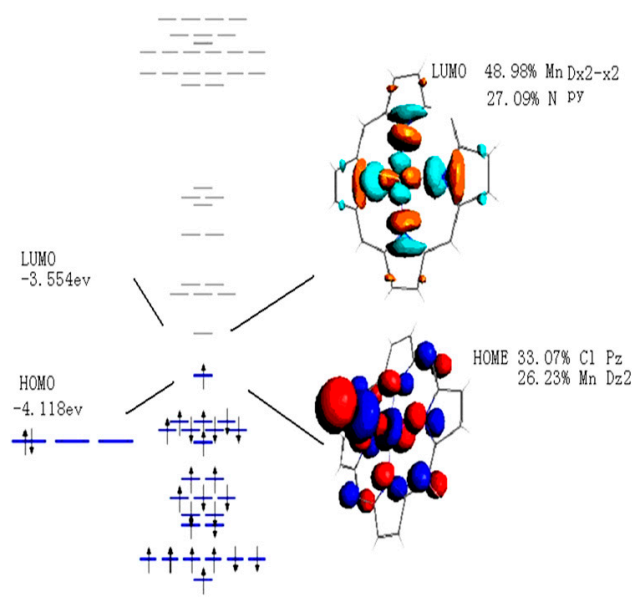

(PMn $\left.{ }^{\mathrm{III}} \mathrm{Cl}\right)$

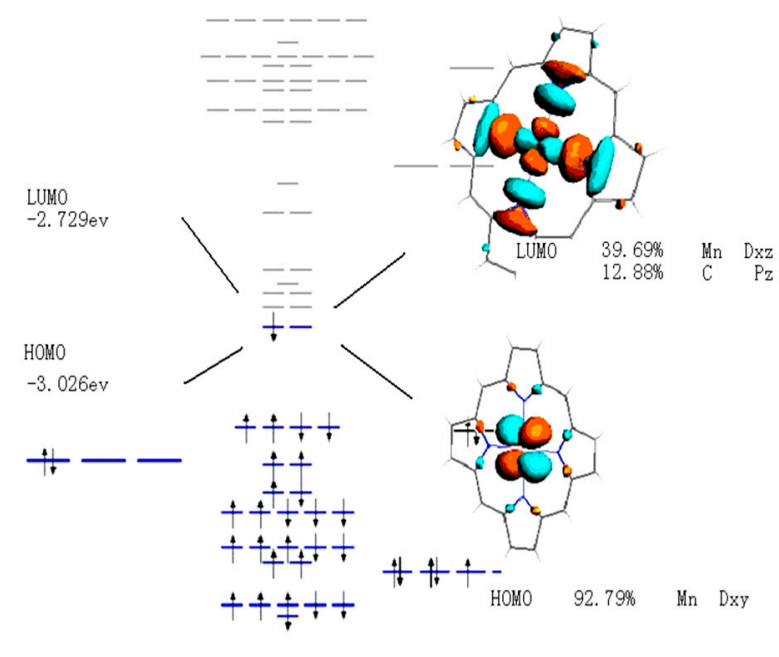

(PMn'I)

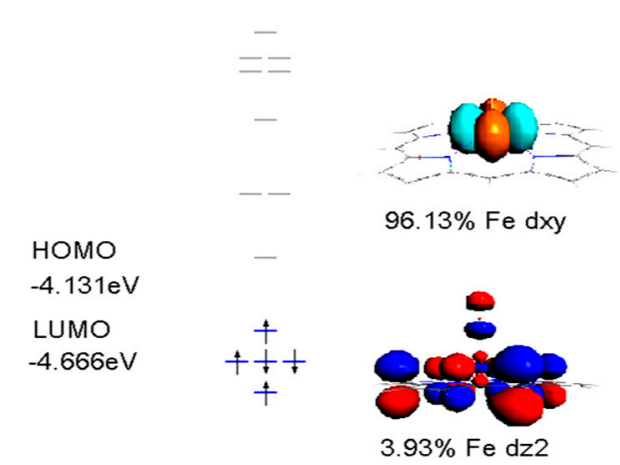

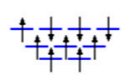

(PFe $\left.{ }^{\mathrm{III}} \mathrm{Cl}\right)$

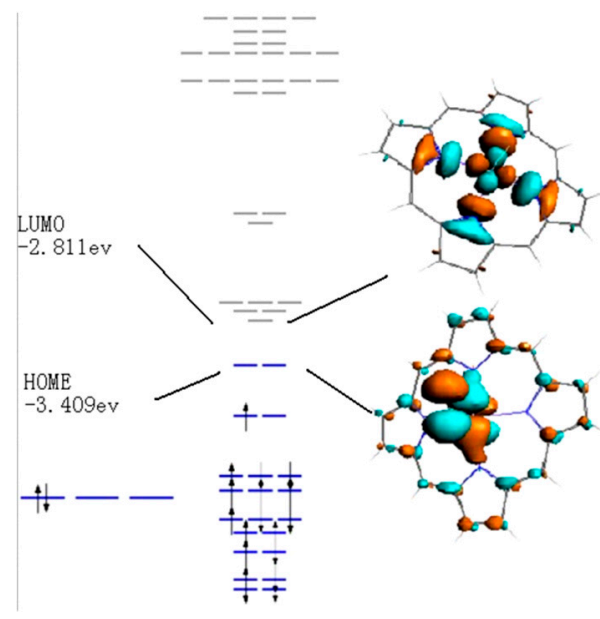

(PCo $\left.{ }^{\mathrm{III}} \mathrm{Cl}\right)$

Figure 6. Frontier molecular orbitals of $\mathrm{PM}^{\mathrm{II}}$ and $\mathrm{PM}^{\mathrm{III}} \mathrm{Cl}(\mathrm{M}=\mathrm{Fe}, \mathrm{Mn}$, and $\mathrm{Co})$. 


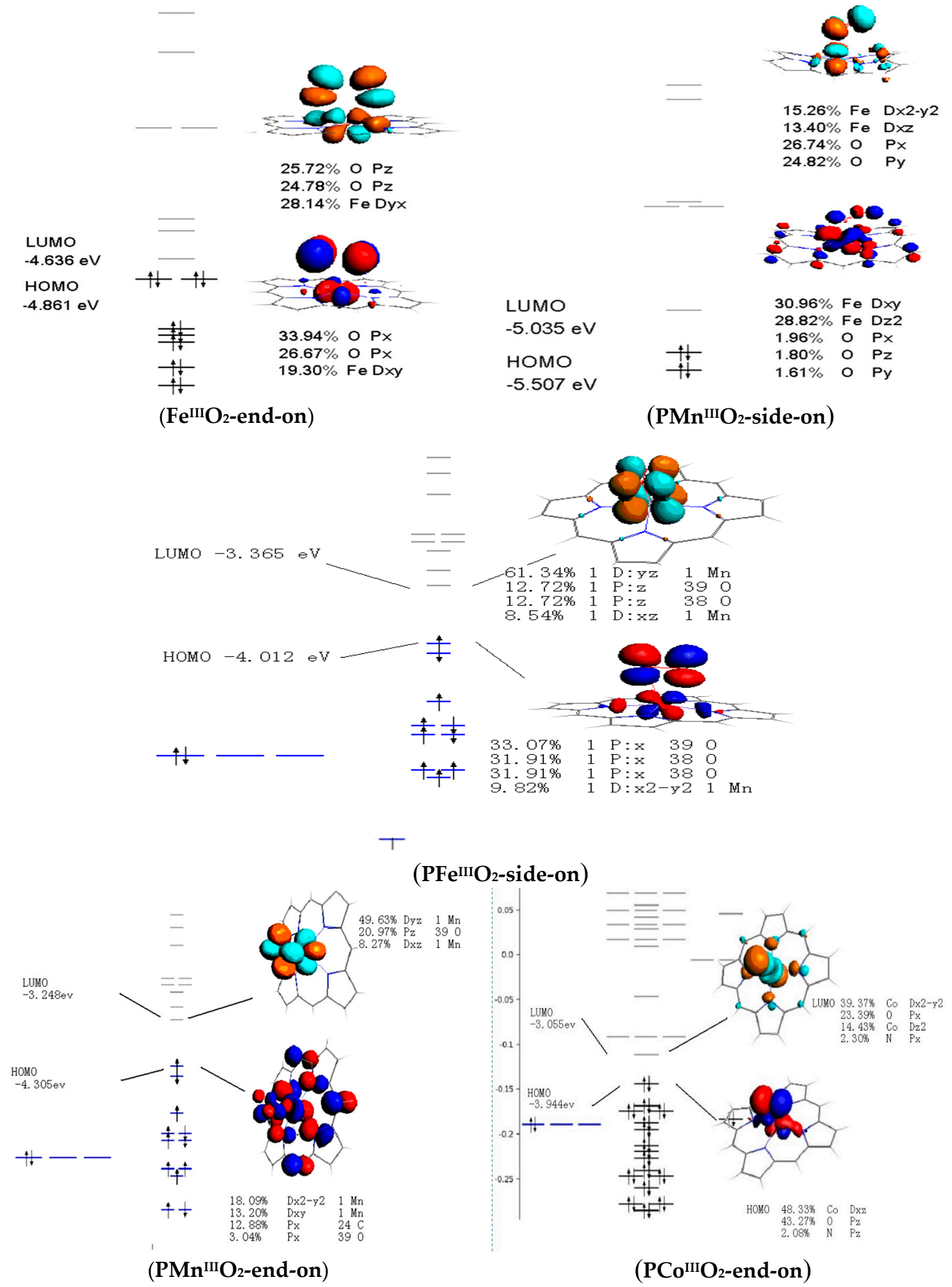

Figure 7. Frontier molecular orbitals of $\mathrm{PM}^{\mathrm{III}}$ and $\mathrm{PM}^{\mathrm{III}}-\mathrm{O}_{2}(\mathrm{M}=\mathrm{Fe}, \mathrm{Mn}$, and Co). 


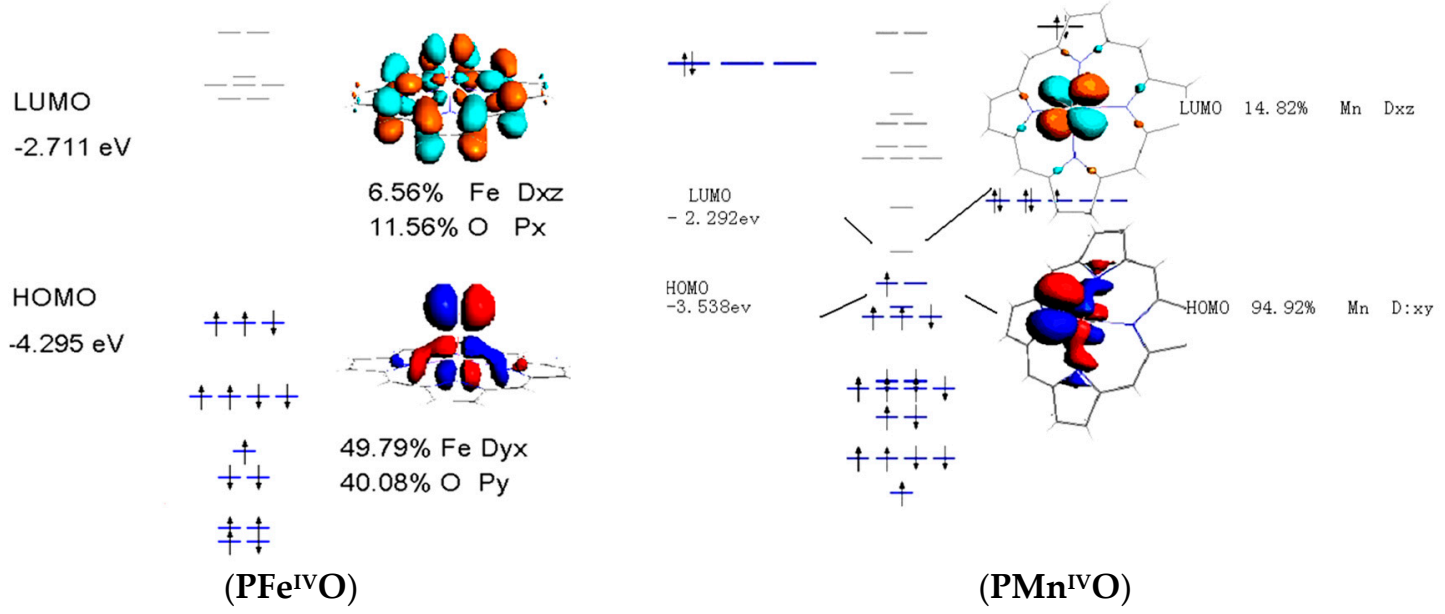

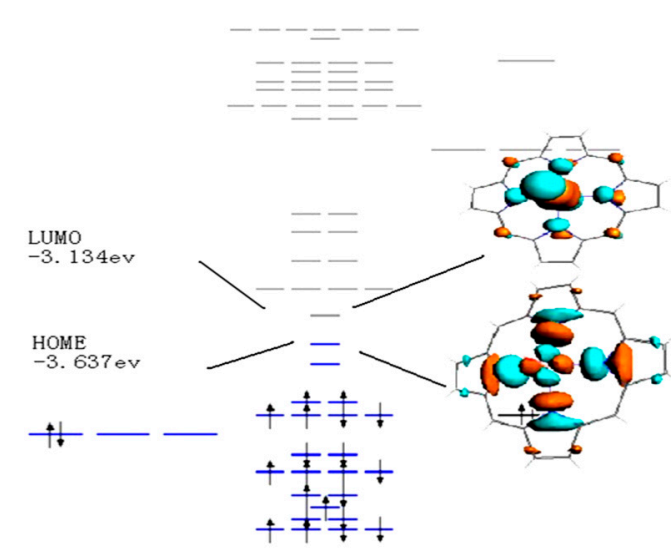

$\left(\mathrm{Co}^{\mathrm{IV}} \mathrm{O}\right)$

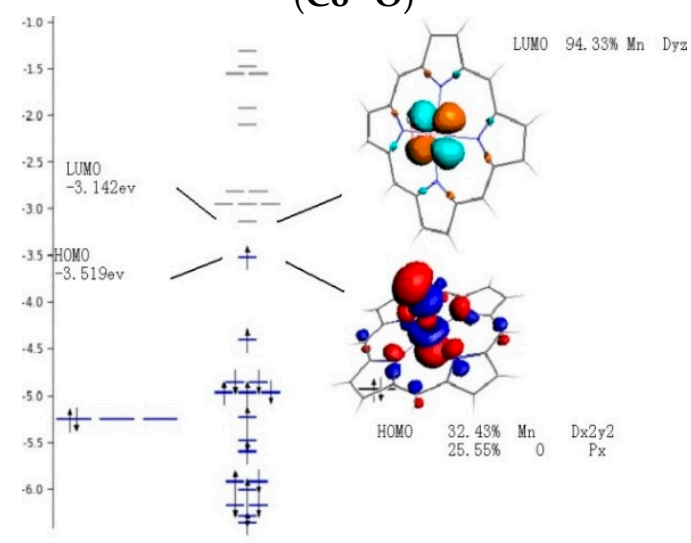

$\left(\mathbf{P M n}{ }^{\mathrm{IIIOH})}\right.$

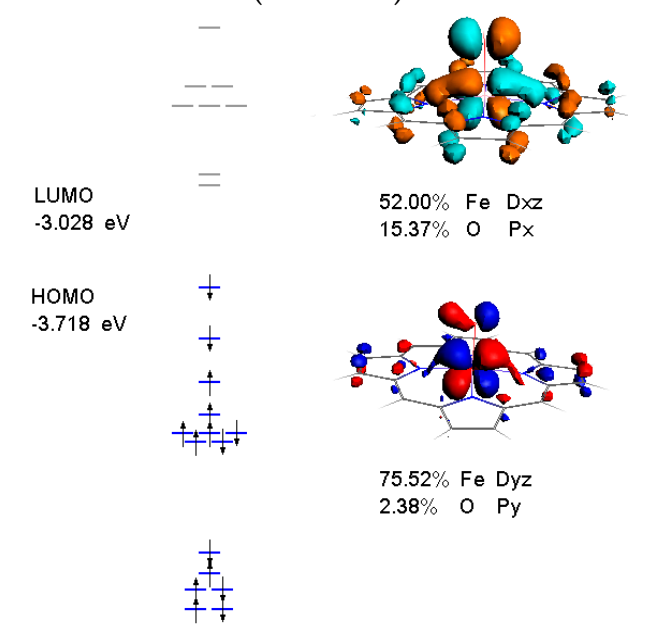

$\left(\mathrm{PFe} \mathrm{eIIOH}^{\mathrm{II}}\right.$

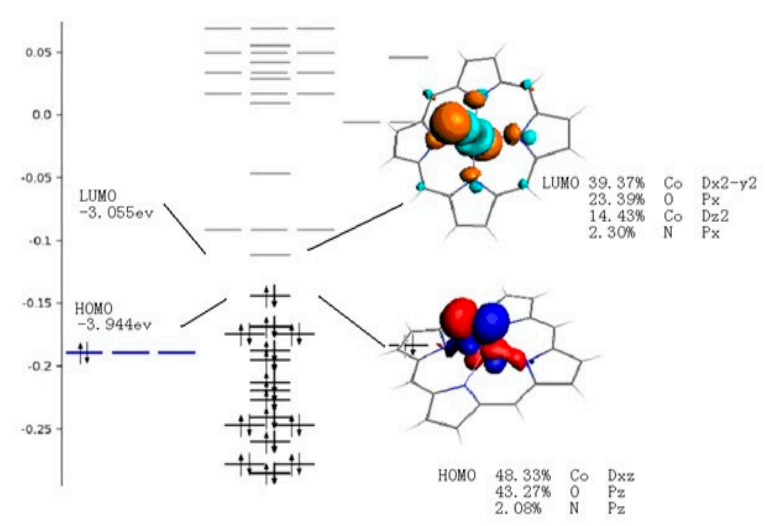

$\left(\mathrm{PCo}{ }^{\mathrm{IIIOH}}\right)$

Figure 8. Frontier molecular orbitals of $\mathrm{PM}^{\mathrm{IV}} \mathrm{O}$ and $\mathrm{PM}{ }^{\mathrm{III}} \mathrm{OH}(\mathrm{M}=\mathrm{Fe}, \mathrm{Mn}$, and $\mathrm{Co})$.

As shown in Figure 8, LUMO of PFe ${ }^{\mathrm{III}} \mathrm{OH}$ was consisted with Fe-dxz and O-px, to form the $\pi^{*}$ orbital of $\mathrm{PFe}{ }^{\mathrm{III}} \mathrm{OH}$. The $\mathrm{HOMO}$ of $\mathrm{PFe}{ }^{\mathrm{III}} \mathrm{OH}$ was made up by Fe-dyz and O-py, generating the $\pi$ orbital of $\mathrm{PFe}{ }^{\mathrm{III}} \mathrm{OH}$. They provided the px,y characters, which is perpendicular to the Fe-O bond. $\mathrm{PMn}{ }^{\mathrm{III}} \mathrm{OH}$ was observed to $\sigma$ bond with $\mathrm{Mn}-\mathrm{dx}^{2}-\mathrm{y}^{2}$ and $\mathrm{O}-\mathrm{p}_{\mathrm{x}}$ orbitals, which provided a character for C-H bond attacking along with the Fe-O bond. Finally, for the $\mathrm{PCo}{ }^{\mathrm{III}} \mathrm{OH}, \mathrm{LUMO}$ has a character of $\mathrm{d}_{\mathrm{z}}{ }^{2}$ $\sigma$, which displayed oxo $p_{x}$ character that is oriented along with $\mathrm{Fe}-\mathrm{O}$ bond. The $\mathrm{HOMO}$ of $\mathrm{PCo}{ }^{\mathrm{III}} \mathrm{OH}$ 
was $\mathrm{d} \pi \mathrm{FMO}$ that is composed of Co-pxz and O- $\mathrm{p}_{z}$, facilitating $\mathrm{C}-\mathrm{H}$ bond attacked perpendicular to Co-O bond. The FMO of $\mathrm{PCo}^{\mathrm{III}} \mathrm{OH}$ provided flexible orientation for $\mathrm{C}-\mathrm{H}$ bond attack and it implied a potential oxidant for $\mathrm{PCo}{ }^{\mathrm{III}} \mathrm{OH}$.

\section{Conclusions}

To summarize, ground states of $\mathrm{PM}^{\mathrm{II}}(\mathrm{M}=\mathrm{Fe}, \mathrm{Mn}$, and $\mathrm{Co})$ were determined by energy assessment and confirmed by experimental results. The geometric structure of intermediates was further analyzed to confirm the ground state. Mulliken charges suggested that non-ligated metalloporphyrin was favorable to activate dioxygen. $\mathrm{Mn}^{\mathrm{II}}$ showed higher activity to dioxygen than $\mathrm{PFe}^{\mathrm{II}}$ and $\mathrm{PCo}^{\mathrm{II}}$. Our results also indicate that $\mathrm{O}$ atom of iron-hydroxo species $\left(\mathrm{PFe}^{\mathrm{III}} \mathrm{OH}\right)$ carried more negative charge than that of high-valent species that showed the potential oxidant ability. Specifically, $\mathrm{PCo}{ }^{\mathrm{III}} \mathrm{OH}$ provided flexible orientation for $\mathrm{C}-\mathrm{H}$ bond attack. Frontier molecular orbital analysis demonstrated that non-ligated $\mathrm{PM}^{\mathrm{II}}$ facilitated activating the dioxygen. These metalloporphyrins provided the flexible orbital orientation that were beneficial to the adduct of dioxygen. The $\mathrm{PFe}^{\mathrm{IV}} \mathrm{O}$ had two $\pi$ and $\pi^{*}$ type orbitals for $\mathrm{C}-\mathrm{H}$ bond attack that is perpendicular to $\mathrm{Fe}-\mathrm{O}$ bond. $\mathrm{PMn}^{\mathrm{IV}}=\mathrm{O}$ only had one $\pi$ type orbital, which facilitated the $\mathrm{C}-\mathrm{H}$ perpendicular attack. $\mathrm{PCo}^{\mathrm{IV}}=\mathrm{O}$ might benefit to the $\mathrm{C}-\mathrm{H}$ bond attack in the orientation than $\mathrm{PFe}^{\mathrm{IV}} \mathrm{O}$ and $\mathrm{PMn}^{\mathrm{IV}}=\mathrm{O}$. $\mathrm{PCo}{ }^{\mathrm{III}} \mathrm{OH}$ exhibited a strong oxidant ability since the $\mathrm{C}-\mathrm{H}$ bond provided the flexible orientation for $\mathrm{C}-\mathrm{H}$ bond attack. Currently, research on the mechanism of $\mathrm{C}-\mathrm{H}$ bond attacking by possible reactive metalloporphyrin intermediates is undergoing in our lab. These studies give novel insights into geometric and electronic structure properties of catalytically active sites, which are likely to provide new understanding of the selective redox roles of metalloporphyrins in biomimetic catalysis and the catalytic behavior of related metaloenzymes in biological processes.

Supplementary Materials: The following are available online at http://www.mdpi.com/2073-4344/10/2/224/s1, Figure S1: Geometric parameters of the ground state for $\mathrm{PM}^{\mathrm{II}}$ ("presents the experimental value), Figure S2: Geometric parameters of the ground state for $\mathrm{PM}^{\mathrm{III}} \mathrm{Cl}$ ( ${ }^{*}$ presents the experimental value), Figure S3: Geometric parameters of side-on and end-on $\mathrm{PM}^{\mathrm{II}}-\mathrm{O}_{2}$ intermediates.

Author Contributions: Conceptualization, M.C. and A.G.; methodology, M.C. and Y.Z.; software, M.C.; validation, Y.L. (Yuanyuan Liu), F.H., M.L. and Y.Y.,; formal analysis, R.L.; investigation, Y.L. (Luhai Li); resources, R.L. and Z.S.; data curation, M.C. and Y.Z.; writing-original draft preparation, M.C.; writing-review and editing, F.H., Z.S. and Y.Z.; visualization, Y.H.; supervision, Y.Z. and L.L.; project administration, Y.Z. and Z.S.; funding acquisition, M.C., Z.S and L.L. All authors have read and agreed to the published version of the manuscript.

Funding: This work was supported by the General and Youth Projects of Natural Science of China (Grant Nos. 21706016, 61971049 and 21776021), the Beijing Municipal Education Commission (Grant Nos. 04190118002/092, 04190118002/042, KZ202010015024 and KZ201910015016), Beijing Municipal Science and Technology Commission (Z181100004418004), Project by Beijing Postdoctoral Research Foundation (ZZ-20160X), BIGC Key Project (Ea201603), and the BIGC Talent Project and Undergraduate Student Research Education Foundation.

Acknowledgments: We also thank Beijing Institute of Graphic Communication and Hainan University for financial support.

Conflicts of Interest: The authors declare no conflict of interest.

\section{References}

1. Seo, M.S.; Kim, N.H.; Cho, K.-B.; So, J.E.; Park, S.K.; Clémancey, M.; Garcia-Serres, R.; Latour, J.-M.; Shaik, S.; Nam, W. A mononuclear nonheme iron (iv)-oxo complex which is more reactive than cytochrome P450 model compound I. Chem. Sci. 2011, 2, 1039-1045. [CrossRef]

2. Shin, J.W.; Rowthu, S.R.; Hyun, M.Y.; Song, Y.J.; Kim, C.; Kim, B.G.; Min, K.S. Monomeric, trimeric, and tetrameric transition metal complexes ( $\mathrm{Mn}, \mathrm{Fe}, \mathrm{Co})$ containing N, N-bis (2-pyridylmethyl)-2-aminoethanol/-ate: Preparation, crystal structure, molecular magnetism and oxidation catalysis. Dalton Trans. 2011, 40, 5762-5773. [CrossRef] [PubMed]

3. Liu, W.; Groves, J.T. Manganese porphyrins catalyze selective C-H bond halogenations. J. Am. Chem. Soc. 2010, 132, 12847-12849. [CrossRef] [PubMed] 
4. Lyons, J.E.; Ellis, P.E., Jr.; Durante, V.A. Active iron oxo centers for the selective catalytic oxidation of Alkanes. In Studies in Surface Science and Catalysis; Elsevier: Boston, MA, USA, 1991; Volume 67, pp. 99-116.

5. Pereira, M.M.; Dias, L.D.; Calvete, M.J. Metalloporphyrins: Bioinspired oxidation catalysts. ACS Catal. 2018, 8, 10784-10808. [CrossRef]

6. Calvete, M.J.; Piñeiro, M.; Dias, L.D.; Pereira, M.M. Hydrogen peroxide and metalloporphyrins in oxidation catalysis: Old dogs with some new tricks. Chem CatChem 2018, 10, 3615-3635. [CrossRef]

7. Yamazaki, S.-I. Metalloporphyrins and related metallomacrocycles as electrocatalysts for use in polymer electrolyte fuel cells and water electrolyzers. Coord. Chem. Rev. 2018, 373, 148-166. [CrossRef]

8. Guimarães, A.S.; Schmitberger, B.; Meireles, A.M.; da Silva Martins, D.C.; DeFreitas-Silva, G. An eco-friendly approach to the cyclohexane oxidation catalyzed by manganese porphyrins: Green and solvent-free systems. Polyhedron 2019, 163, 144-152. [CrossRef]

9. Dong, H.; Xu, S.; Wang, J.; Chen, Y.; Bi, L.; Zhao, Z. Selective aerobic allylic oxidation of $\alpha$-pinene catalyzed by metalloporphyrins in the absence of solvents and additives. J. Chem. Res. 2019, 43, 419-425. [CrossRef]

10. Li, Y.; Zhou, X.; Chen, S.; Luo, R.; Jiang, J.; Liang, Z.; Ji, H. Direct aerobic liquid phase epoxidation of propylene catalyzed by $\mathrm{Mn}$ (iii) porphyrin under mild conditions: Evidence for the existence of both peroxide and Mn (iv)-oxo species from in situ characterizations. RSC Adv. 2015, 5, 30014-30020. [CrossRef]

11. Zhou, X.; Ji, H. Manganese porphyrin immobilized on montmorillonite: A highly efficient and reusable catalyst for the aerobic epoxidation of olefins under ambient conditions. J. Porphyr. Phthalocyanines 2012, 16, 1032-1039. [CrossRef]

12. Hunt, A.P.; Lehnert, N. The Thiolate Trans Effect in Heme $\{\mathrm{FeNO}\}^{6}$ Complexes and Beyond: Insight into the Nature of the Push Effect. Inorg. Chem. 2019, 58, 11317-11332. [CrossRef] [PubMed]

13. Jiang, J.; Luo, R.; Zhou, X.; Chen, Y.; Ji, H. Photocatalytic Properties and Mechanistic Insights into Visible Light-Promoted Aerobic Oxidation of Sulfides to Sulfoxides via Tin Porphyrin-Based Porous Aromatic Frameworks. Adv. Synth. Catal. 2018, 360, 4402-4411. [CrossRef]

14. Li, C.; Lang, K.; Lu, H.; Hu, Y.; Cui, X.; Wojtas, L.; Zhang, X.P. Catalytic Radical Process for Enantioselective Amination of C (sp3)-H Bonds. Angew. Chem. Int. Ed. 2018, 130, 17079-17083. [CrossRef]

15. Lang, K.; Torker, S.; Wojtas, L.; Zhang, X.P. Asymmetric Induction and Enantiodivergence in Catalytic Radical C-H Amination via Enantiodifferentiative H-Atom Abstraction and Stereoretentive Radical Substitution. J. Am. Chem. Soc. 2019, 141, 12388-12396. [CrossRef]

16. Lv, X.-L.; Wang, K.; Wang, B.; Su, J.; Zou, X.; Xie, Y.; Li, J.-R.; Zhou, H.-C. A Base-Resistant Metalloporphyrin Metal-Organic Framework for C-H Bond Halogenation. J. Am. Chem. Soc. 2017, 139, 211-217. [CrossRef]

17. Gan, T.; Zhang, H.; Liu, Y.; He, Q.; Zhang, Y.; He, X.; Ji, H. Self-Assembled Metalloporphyrins-Magnesium Phosphate Hybrid Spheres as Efficient Catalysts for Cycloaddition of Carbon Dioxide. ChemistrySelect 2019, 4, 8233-8236. [CrossRef]

18. Chen, Y.; Luo, R.; Yang, Z.; Zhou, X.; Ji, H. Imidazolium-based ionic liquid decorated zinc porphyrin catalyst for converting $\mathrm{CO}_{2}$ into five-membered heterocyclic molecules. Sustain. Energy Fuels 2018, 2, 125-132. [CrossRef]

19. Dong, Y.; Nie, R.; Wang, J.; Yu, X.; Tu, P.; Chen, J.; Jing, H. Photoelectrocatalytic $\mathrm{CO}_{2}$ reduction based on metalloporphyrin-modified $\mathrm{TiO}_{2}$ photocathode. Chin. J. Catal. 2019, 40, 1222-1230. [CrossRef]

20. Leung, K.; Nielsen, I.M.; Sai, N.; Medforth, C.; Shelnutt, J.A. Cobalt-porphyrin catalyzed electrochemical reduction of carbon dioxide in water. 2. mechanism from first principles. J. Phys. Chem. A 2010, 114, 10174-10184. [CrossRef]

21. Ali, M.E.; Sanyal, B.; Oppeneer, P.M. Electronic structure, spin-states, and spin-crossover reaction of heme-related Fe-porphyrins: A theoretical perspective. J. Phys. Chem. B 2012, 116, 5849-5859. [CrossRef]

22. Kaizer, J.; Klinker, E.J.; Oh, N.Y.; Rohde, J.-U.; Song, W.J.; Stubna, A.; Kim, J.; Münck, E.; Nam, W.; Que, L. Nonheme FeIVO complexes that can oxidize the $\mathrm{C}-\mathrm{H}$ bonds of cyclohexane at room temperature. J. Am. Chem. Soc. 2004, 126, 472-473. [CrossRef] [PubMed]

23. Nam, W. High-valent iron (IV)-oxo complexes of heme and non-heme ligands in oxygenation reactions. Acc. Chem. Res. 2007, 40, 522-531. [CrossRef] [PubMed]

24. Altun, A.; Shaik, S.; Thiel, W. What is the active species of cytochrome P450 during camphor hydroxylation? QM/MM studies of different electronic states of compound I and of reduced and oxidized iron-oxo intermediates. J. Am. Chem. Soc. 2007, 129, 8978-8987. [CrossRef] [PubMed] 
25. Song, W.J.; Seo, M.S.; DeBeer George, S.; Ohta, T.; Song, R.; Kang, M.-J.; Tosha, T.; Kitagawa, T.; Solomon, E.I.; Nam, W. Synthesis, Characterization, and Reactivities of Manganese(V)-Oxo Porphyrin Complexes. J. Am. Chem. Soc. 2007, 129, 1268-1277. [CrossRef] [PubMed]

26. Charnock, J.M.; Garner, C.D.; Trautwein, A.X.; Bill, E.; Winkler, H.; Ayougou, K.; Mandon, D.; Weiss, R. Characterization of an Oxo (porphyrinato) manganese (iv) Complex by X-ray Absorption Spectroscopy. Angew. Chem. Int. Ed. 1995, 34, 343-346. [CrossRef]

27. Arasasingham, R.D.; He, G.X.; Bruice, T.C. Mechanism of manganese porphyrin-catalyzed oxidation of alkenes. Role of manganese (IV)-oxo species. J. Am. Chem. Soc. 1993, 115, 7985-7991. [CrossRef]

28. Chen, J.; Lee, Y.-M.; Davis, K.M.; Wu, X.; Seo, M.S.; Cho, K.-B.; Yoon, H.; Park, Y.J.; Fukuzumi, S.; Pushkar, Y.N. A Mononuclear Non-Heme Manganese(IV)-Oxo Complex Binding Redox-Inactive Metal Ions. J. Am. Chem. Soc. 2013, 135, 6388-6391. [CrossRef]

29. Taguchi, T.; Gupta, R.; Lassalle-Kaiser, B.; Boyce, D.W.; Yachandra, V.K.; Tolman, W.B.; Yano, J.; Hendrich, M.P.; Borovik, A. Preparation and properties of a monomeric high-spin MnV-oxo complex. J. Am. Chem. Soc. 2012, 134, 1996-1999. [CrossRef]

30. Liu, J.G.; Ohta, T.; Yamaguchi, S.; Ogura, T.; Sakamoto, S.; Maeda, Y.; Naruta, Y. Spectroscopic Characterization of a Hydroperoxo-Heme Intermediate: Conversion of a Side-On Peroxo to an End-On Hydroperoxo Complex. Angew. Chem. Int. Ed. 2009, 48, 9262-9267. [CrossRef]

31. Liu, J.-G.; Shimizu, Y.; Ohta, T.; Naruta, Y. Formation of an end-on ferric peroxo intermediate upon one-electron reduction of a ferric superoxo heme. J. Am. Chem. Soc. 2010, 132, 3672-3673. [CrossRef]

32. Liao, M.-S.; Watts, J.D.; Huang, M.-J. Electronic structure of some substituted iron (II) porphyrins. Are they intermediate or high spin? J. Phys. Chem. A 2007, 111, 5927-5935. [CrossRef] [PubMed]

33. Rutkowska-Zbik, D.; Tokarz-Sobieraj, R.; Witko, M. Quantum chemical description of oxygen activation process on Co, Mn, and Mo porphyrins. J. Chem. Theory Comput. 2007, 3, 914-920. [CrossRef] [PubMed]

34. Chen, H.; Cho, K.-B.; Lai, W.; Nam, W.; Shaik, S. Dioxygen activation by a non-heme iron (II) complex: Theoretical study toward understanding ferric-superoxo complexes. J. Chem. Theory Comput. 2012, 8, 915-926. [CrossRef] [PubMed]

35. Silaghi-Dumitrescu, R. A density functional investigation of hydrogen peroxide activation by high-valent heme centers: Implications for the catalase catalytic cycle. J. Porphyr. Phthalocyanines 2010, 14, 371-374. [CrossRef]

36. Hill, C.L.; Schardt, B.C. Alkane activation and functionalization under mild conditions by a homogeneous manganese (III) porphyrin-iodosylbenzene oxidizing system. J. Am. Chem. Soc. 1980, 102, 6374-6375. [CrossRef]

37. Kameyama, H.; Narumi, F.; Hattori, T.; Kameyama, H. Oxidation of cyclohexene with molecular oxygen catalyzed by cobalt porphyrin complexes immobilized on montmorillonite. J. Mol. Catal. A Chem. 2006, 258, 172-177. [CrossRef]

38. Conradie, M.M.; Conradie, J.; Ghosh, A. A DFT overview of high-valent iron, cobalt and nickel tetraamidomacrocyclic ligand (TAML) complexes: The end of innocence? J. Inorg. Biochem. 2006, 100, 620-626. [CrossRef]

39. Chen, Y.; She, Y.; Xu, J.; Li, Y. Studies on QSAR of metalloporphyrin catalysts in the oxidation of cyclohexane to adipic acid. Front. Chem. Eng. China 2007, 1, 155-161. [CrossRef]

40. Conradie, J.; Ghosh, A. Iron (III)-Nitro Porphyrins: Theoretical Exploration of a Unique Class of Reactive Molecules. Inorg. Chem. 2006, 45, 4902-4909. [CrossRef]

41. Conradie, J.; Ghosh, A. Electronic Structure of an Iron-Porphyrin-Nitrene Complex. Inorg. Chem. 2009, 49, 243-248. [CrossRef]

42. Que, L.; Watanabe, Y. Oxygenase pathways: Oxo, peroxo, and superoxo. Science 2001, 292, 651-653. [PubMed]

43. Groves, J.T.; Han, Y.-Z. Models and mechanisms of cytochrome P450 action. In Cytochrome P450; Springer: Boston, MA, USA, 1995; pp. 3-48.

44. Haber, J.; Matachowski, L.; Pamin, K.; Połtowicz, J. Manganese porphyrins as catalysts for oxidation of cyclooctane in Lyons system. J. Mol. Catal. A Chem. 2000, 162, 105-109. [CrossRef]

45. Chin, D.-H.; La Mar, G.N.; Balch, A.L. Mechanism of autoxidation of iron (II) porphyrins. Detection of a peroxo-bridged iron (III) porphyrin dimer and the mechanism of its thermal decomposition to the oxo-bridged iron (III) porphyrin dimer. J. Am. Chem. Soc. 1980, 102, 4344-4350. [CrossRef] 
46. Ghiladi, R.A.; Kretzer, R.M.; Guzei, I.; Rheingold, A.L.; Neuhold, Y.-M.; Hatwell, K.R.; Zuberbühler, A.D.; Karlin, K.D. (F $\left.\mathrm{F}_{8} \mathrm{TPP}\right) \mathrm{Fe}^{\mathrm{II}} / \mathrm{O}_{2}$ Reactivity Studies $\left\{\mathrm{F}_{8} \mathrm{TPP}=\right.$ Tetrakis(2,6-difluorophenyl)porphyrinate(2-)\}: Spectroscopic (UV-Visible and NMR) and Kinetic Study of Solvent-Dependent $\left(\mathrm{Fe} / \mathrm{O}_{2}=1: 1\right.$ or 2:1) Reversible $\mathrm{O}_{2}$-Reduction and Ferryl Formation. Inorg. Chem. 2001, 40, 5754-5767. [CrossRef] [PubMed]

47. Blomberg, M.R.; Johansson, A.J.; Siegbahn, P.E. O-O Bond Cleavage in Dinuclear Peroxo Complexes of Iron Porphyrins: A Quantum Chemical Study. Inorg. Chem. 2007, 46, 7992-7997. [CrossRef] [PubMed]

48. Hunt, A.P.; Lehnert, N. Heme-nitrosyls: Electronic structure implications for function in biology. Acc. Chem. Res. 2015, 48, 2117-2125. [CrossRef] [PubMed]

49. Guerra, C.F.; Snijders, J.; te Velde, G.; Baerends, E.J. Towards an order-N DFT method. Theor. Chem. Acc. 1998, 99, 391-403.

50. Te Velde, G.t.; Bickelhaupt, F.M.; Baerends, E.J.; Fonseca Guerra, C.; van Gisbergen, S.J.; Snijders, J.G.; Ziegler, T. Chemistry with ADF. J. Comput. Chem. 2001, 22, 931-967. [CrossRef]

51. Bickelhaupt, F.M.; Baerends, E.J. Kohn-Sham density functional theory: Predicting and understanding chemistry. Rev. Com. Chem. 2000, 15, 1-86.

52. Hoe, W.-M.; Cohen, A.J.; Handy, N.C. Assessment of a new local exchange functional OPTX. Chem. Phys. Lett. 2001, 341, 319-328. [CrossRef]

53. Hertwig, R.H.; Koch, W. On the parameterization of the local correlation functional. What is Becke-3-LYP? Chem. Phys. Lett. 1997, 268, 345-351. [CrossRef]

54. Conradie, M.M.; Conradie, J.; Ghosh, A. Capturing the spin state diversity of iron (III)-aryl porphyrins: OLYP is better than TPSSh. J. Inorg. Biochem. 2011, 105, 84-91. [CrossRef] [PubMed]

55. Conradie, J.; Ghosh, A. Electronic Structure of Trigonal-Planar Transition-Metal-Imido Complexes: Spin-State Energetics, Spin-Density Profiles, and the Remarkable Performance of the OLYP Functional. J. Chem. Theory Comput. 2007, 3, 689-702. [CrossRef] [PubMed]

56. Radon, M.; Pierloot, K. Binding of $\mathrm{CO}, \mathrm{NO}$, and $\mathrm{O}_{2}$ to Heme by Density Functional and Multireference ab Initio Calculations. J. Phys. Chem. A 2008, 112, 11824-11832. [CrossRef] [PubMed]

57. Gonzalez, E.; Brothers, P.J.; Ghosh, A. Density Functional Theory Calculations on Ruthenium(IV) Bis(amido) Porphyrins: Search for a Broader Perspective of Heme Protein Compound II Intermediates. J. Phys. Chem. B 2010, 114, 15380-15388. [CrossRef]

58. Jaworska, M.; Lodowski, P. Electronic structure and spectra of nitrosyl complexes with cobalt and manganese porphyrins. Struct. Chem. 2012, 23, 1333-1348. [CrossRef]

59. Liao, M.-S.; Scheiner, S. Electronic structure and bonding in unligated and ligated Fe II porphyrins. J. Chem. Phys. 2002, 116, 3635-3645. [CrossRef]

60. Mispelter, J.; Momenteau, M.; Lhoste, J. Proton magnetic resonance characterization of the intermediate $(S=$ 1) spin state of ferrous porphyrins. J. Chem. Phys. 1980, 72, 1003-1012. [CrossRef]

61. Liao, M.S.; Scheiner, S. Comparative study of metal-porphyrins,-porphyrazines, and-phthalocyanines. J. Comput. Chem. 2002, 23, 1391-1403. [CrossRef]

62. Lin, W. d-Orbital energies and low-lying excited states of cobalt porphyrins. Inorg. Chem. 1976, 15, 1114-1118. [CrossRef]

63. Nakamura, K.; Kitaoka, Y.; Akiyama, T.; Ito, T.; Weinert, M.; Freeman, A.J. Constraint density functional calculations for multiplets in a ligand-field applied to Fe-phthalocyanine. Phys. Rev. B 2012, 85, 235129. [CrossRef]

64. Panchmatia, P.M.; Ali, M.E.; Sanyal, B.; Oppeneer, P.M. Halide ligated iron porphines: A DFT+ U and UB3LYP study. J. Phys. Chem. A 2010, 114, 13381-13387. [CrossRef] [PubMed]

65. Johansson, M.P.; Sundholm, D. Spin and charge distribution in iron porphyrin models: A coupled cluster and density-functional study. J. Chem. Phys. 2004, 120, 3229-3236. [CrossRef] [PubMed]

66. Kennedy, B.J.; Murray, K.S.; Zwack, P.R.; Homborg, H.; Kalz, W. Spin states in iron (III) phthalocyanines studied by Moessbauer, magnetic susceptibility, and ESR measurements. Inorg. Chem. 1986, 25, 2539-2545. [CrossRef]

67. Kepenekian, M.; Calborean, A.; Vetere, V.; Le Guennic, B.; Robert, V.; Maldivi, P. Toward reliable dft investigations of mn-porphyrins through CASPT2/DFT comparison. J. Chem. Theory Comput. 2011, 7, 3532-3539. [CrossRef]

68. Shaik, S.; Hirao, H.; Kumar, D. Reactivity of high-valent iron-oxo species in enzymes and synthetic reagents: A tale of many states. Acc. Chem. Res. 2007, 40, 532-542. [CrossRef] 
69. Yin, G. Understanding the Oxidative Relationships of the Metal Oxo, Hydroxo, and Hydroperoxide Intermediates with Manganese(IV) Complexes Having Bridged Cyclams: Correlation of the Physicochemical Properties with Reactivity. Acc. Chem. Res. 2012, 46, 483-492. [CrossRef]

70. Groenhof, A.R.; Swart, M.; Ehlers, A.W.; Lammertsma, K. Electronic ground states of iron porphyrin and of the first species in the catalytic reaction cycle of cytochrome P450s. J. Phys. Chem. A 2005, 109, 3411-3417. [CrossRef]

71. Collman, J.P.; Hoard, J.; Kim, N.; Lang, G.; Reed, C.A. Synthesis, stereochemistry, and structure-related properties of. .alpha.,.beta.,.gamma.,.delta.-tetraphenylporphinatoiron(II). J. Am. Chem. Soc. 1975, 97, 2676-2681. [CrossRef]

72. Wondimagegn, T.; Rauk, A. The Structures and Stabilities of the Complexes of Biologically Available Ligands with Fe (II) Porphine: An Ab Initio Study. J. Phys. Chem. B 2012, 116, 10301-10310. [CrossRef]

73. Scheidt, W.R.; Finnegan, M.G. Structure of monoclinic chloro (meso-tetraphenylporphyrinato) iron (III). Acta Crystallogr. Sect. C Cryst. Struct. Commun. 1989, 45, 1214-1216. [CrossRef] [PubMed]

74. Cheng, B.; Scheidt, W.R. Chloro(5,10,15,20-tetraphenylporphyrinato)manganese(III) with 4/m Symmetry. Acta Crystallogr. Sect. C Cryst. Struct. Commun. 1996, 52, 361-363. [CrossRef] [PubMed]

75. Madura, P.; Scheidt, W.R. Stereochemistry of low-spin cobalt porphyrins. .alpha.,.beta.,.gamma.,.delta.-Tetraphenylporphinatocobalt(II). Inorg. Chem. 1976, 15, 3182-3184. [CrossRef]

76. Scheidt, W.R. Stereochemistry of low-spin cobalt porphyrins. III. Crystal structure and molecular stereochemistry of bis(piperidine)-.alpha.,.beta.,.gamma.,.delta.-tetraphenylporphinatocobalt(II). J. Am. Chem. Soc. 1974, 96, 84-89. [CrossRef] [PubMed]

(C) 2020 by the authors. Licensee MDPI, Basel, Switzerland. This article is an open access article distributed under the terms and conditions of the Creative Commons Attribution (CC BY) license (http://creativecommons.org/licenses/by/4.0/). 